\title{
Working
}

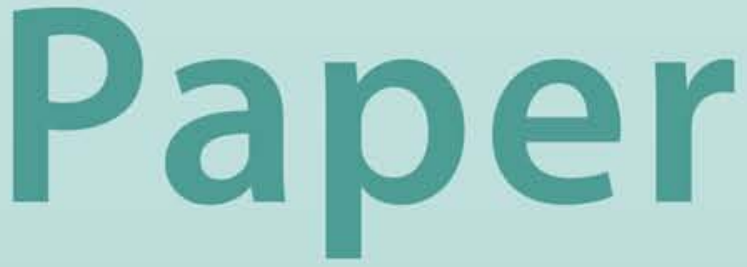


The IMF and Russia in the 1990s

John Odling-Smee 


\title{
IMF Working Paper
}

\author{
European Department
}

\section{The IMF and Russia in the 1990s}

Prepared by John Odling-Smee ${ }^{1}$

August 2004

\begin{abstract}
This Working Paper should not be reported as representing the views of the IMF. The views expressed in this Working Paper are those of the author(s) and do not necessarily represent those of the IMF or IMF policy. Working Papers describe research in progress by the author(s) and are published to elicit comments and to further debate.

This paper explains the IMF's impact on economic policies in Russia, focusing on where the IMF made a difference. The Russian economic and political leadership essentially determined economic policies. The IMF's influence was modest: it had only a limited impact on overall fiscal policy and the major structural reforms, but it had a positive impact on monetary policy. A tougher position on fiscal policy in 1996-98 might have produced a better outcome. The G-7's concerns weakened the IMF. However, the IMF played a major role in transferring knowledge about macroeconomic policymaking and implementation.

JEL Classification Numbers: E60, E62, P20, P34, P35

Keywords: Economic transition, International Monetary Fund, macroeconomic policy, Russia

Author's E-Mail Address: jodlingsmee@juno.com

${ }^{1}$ John Odling-Smee was Director of the European II Department of the IMF from 1992 to 2003. He thanks Gérard Bélanger, José Fajgenbaum, Yegor Gaidar, Oleh Havrylyshyn, Ernesto Hernández-Catá, David Owen, Emil Sunley, Poul Thomsen, Siddharth Tiwari, Thomas Wolf, and Mikhail Zadornov for many helpful comments. Aidar Abdychev and Franziska Ohnsorge provided valuable assistance. The author is responsible for the views expressed here and any errors.
\end{abstract}




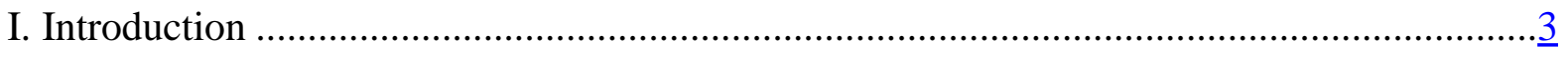

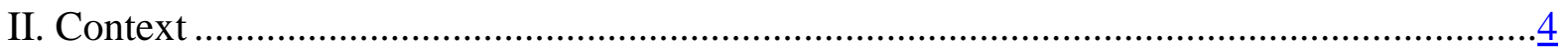

A. Economic Policy Views of the Russian Authorities …....................................... 4

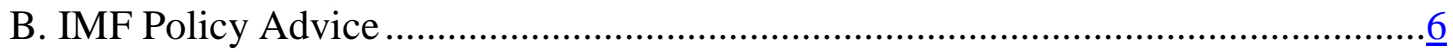

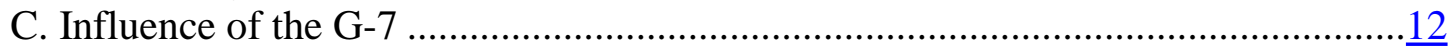

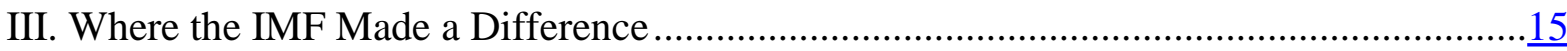

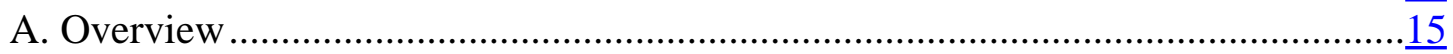

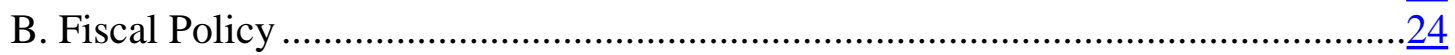

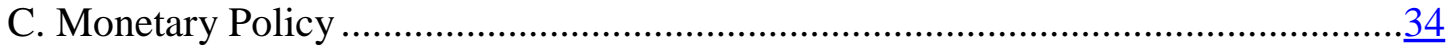

D. Exchange Rate Policy ..........................................................................

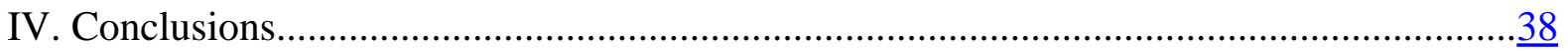

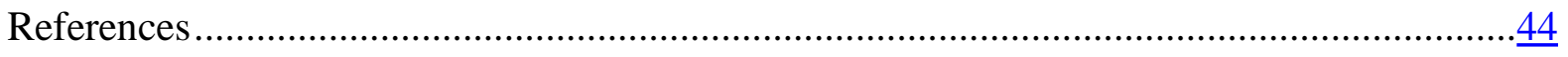

Boxes

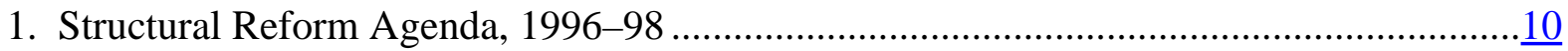

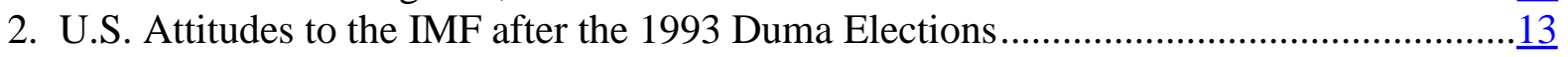

Tables

1. IMF Lending to Russia, by Type of Arrangement................................................

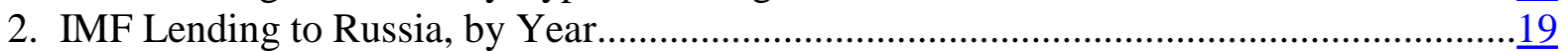

3. Delays in Disbursements Under the Extended Fund Facility ...................................... 27

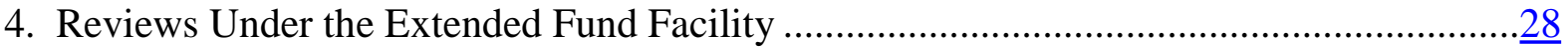

Figures

1. General Government Deficit ................................................................................ $\frac{18}{18}$

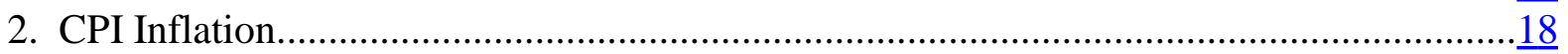

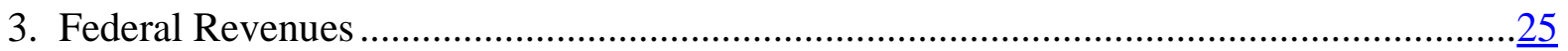

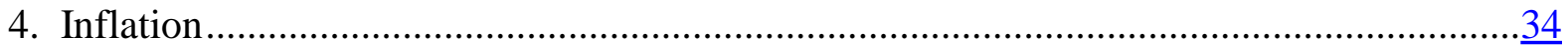

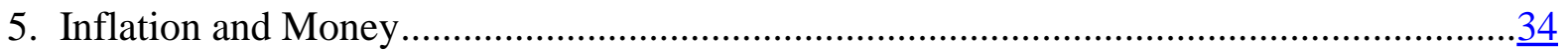

Annex: Channels for IMF Advice............................................................................

Annex Tables

A.1. IMF Technical Assistance Work in Russia ............................................................ 42

A.2. IMF Technical Assistance in the Fiscal Area ......................................................... 


\section{INTRODUCTION}

A remarkably wide range of views has been expressed about the role of the IMF in Russia in the 1990s. Some people believe that most of the economic problems of Russia were attributable to the economic reform policies of successive Russian governments and that those policies were in turn pressed on them by the IMF. ${ }^{2}$ Others believe that the IMF's influence in Russia was minor. Both Russian and foreign commentators can be found in both camps. The purpose of this paper is to explain the role of the IMF in Russia, as seen by a senior member of the IMF staff team working on Russia.

The IMF's role could be assessed in various ways. First, one could assess the quality and relevance of the advice and technical assistance given by the IMF. Second, one could identify where and how the IMF affected economic policy in practice. This would include questions such as whether Russia would have pursued different policies had there been no IMF activity, and whether the policies actually implemented were those recommended by the IMF. Third, one could assess how beneficial or otherwise was the impact of IMF advice and technical assistance on economic policy and outcomes in Russia. This would build on the conclusions of the second approach by assessing the quality of the impact the IMF actually had.

This paper focuses on the second of these. It does not attempt the first, namely an analysis of the quality and relevance of IMF policy advice. Much of the debate about economic policies in Russia, especially among non-Russian commentators, has been about this issue. ${ }^{3}$ There has been much less discussion about the impact the IMF actually had, which is the focus of the second approach. An assessment of the quality of IMF efforts, the third approach listed above, is also not attempted here in a systematic way.

The paper is intended to contribute to a better understanding of one particular aspect of economic policymaking in Russia in the 1990s. It also places on the public record information about the IMF's activities at a very important time.

Section II sets the scene by summarizing various elements of the context of the IMF's work in Russia: the views of the Russian authorities about economic reforms, the key elements of IMF policy advice, and the influence of the Group of Seven major industrial countries (G-7) on relations between the IMF and Russia in the 1990s. Section III then assesses where and how the IMF made a difference to Russian economic policy. It focuses on macroeconomic stabilization, which was the IMF's main concern. Some conclusions are drawn in section IV.

\footnotetext{
${ }^{2}$ For example, Stiglitz (2002) wrote, “The IMF strategy did not work: GDP in post-1989 Russia fell, year after year" (p. 146).

${ }^{3}$ For recent discussions of economic policy issues by IMF staff, see Owen and Robinson (2003) for the period since 1998, and Owen (2004) for the 1995-98 period.
} 


\section{CONTEXT}

\section{A. Economic Policy Views of the Russian Authorities}

Throughout the 1990s, the Russian government's public position was to pursue liberal economic reforms that would lead to the rapid establishment of a market economy. The intellectual leadership for these policies was provided by a relatively small group of economists and others who were committed to market reforms. The starting point was the government formed by President Yeltsin in November 1991, in which Yegor Gaidar was the deputy prime minister with responsibility for economic reforms. Gaidar, who remained in government until December 1992 (for the last six months as acting prime minister), and returned for four months as first deputy prime minister in September 1993, and Anatoly Chubais (deputy prime minister from November 1991 until early 1996 and again in 1997) were the main leaders of the reform group.

However, there was also opposition to economic reforms within government. The strongest strand of alternative thinking came initially from those who saw the primary economic function of government as being to support production. Their views reflected the Soviet system rather than a market economy in which enterprises adjust to changing conditions, especially changing relative prices and profitability and the collapse in demand for military products, within a framework set by the government. They did not wish to return to central planning, but they sought to use the government's fiscal and regulatory powers, and the allocation of Central Bank of Russia (CBR) credits, to encourage the continuation and growth of production, even in sectors that objectively had little future. Various deputy prime ministers (for example, Oleg Soskovets, Oleg Lobov, and Vladimir Kadannikov) and ministers dealing with sectors of the economy formed the heart of this group. Victor Chernomyrdin, prime minister from December 1992 until March 1998, was in the same camp by background, but as prime minister, he had to listen to the president and take account of reformers' views. Yeltsin's own position, as revealed by his speeches and appointments, suggested that he was close to the reformers, although he sometimes turned against them when politics required. Parliament also had an influence on economic policy through the legislation it passed. The Supreme Soviet until it was dissolved in September 1993 (and its buildings stormed in October), and the Duma from its inauguration in December 1993, were more often on the side of protecting production than supporting liberal economic reforms.

The opposition to the reformers not only had different ideas about economic reforms; in many cases, they also had more operational experience and knew how to make the bureaucracy work in pursuit of their interests or to impede the reformers' policy initiatives. This was especially true in 1992 when the reformers underestimated the bureaucratic and other obstacles in their way, and placed too much faith in Yeltsin's ability to make things happen. Gradually, the reformers learned how to get things done, with Chubais emerging as a particularly skilled operator. 
Economic policymaking suffered not only from differences of view within the government, but also from the weakness of the state itself. There was a vacuum created by the collapse of the coercive communist system and the Communist Party network, which together had ensured that government policy was implemented. This was filled by various business and interest groups as well as by criminals. Many businessmen and some criminals had already learned in the Soviet period how to exploit loopholes in the system: for example, by buying goods at controlled prices and selling them at black market prices, and bribing officials whenever necessary. Regional governors and legislators openly defied the federal authorities. Yeltsin was not able to retain the enormous authority that he had acquired from standing up to the leaders of the coup in August 1991 and precipitating the breakup of the Soviet Union. In this, he was handicapped by poor health, especially after 1995 . He tried to retain what influence he could; for example, by agreeing on transfers of power to regional levels on an ad hoc basis. ${ }^{4}$ But neither he nor the government ever had enough broad-based popular support to pursue economic reforms without at least tacit support from powerful groups in the Parliament, regions, and economy.

Business leaders had a very important influence on economic policy in the early 1990s. Enterprises were finding it difficult to adapt to the new environment in which they had to react to financial signals (e.g., changes in profitability and prices) rather than instructions from economic planners. They therefore sought protection or financial assistance from the government and the CBR to help them through the adjustment phase. While in public they usually asked only for temporary assistance, it is likely that in practice many hoped for permanent assistance or even an end to the market reforms that were causing them so much difficulty. Victor Gerashchenko, Chairman of the CBR from July 1992 to November 1994, was initially sympathetic to the view that the CBR and government should deemphasize the goal of cutting inflation and instead support production, although he gradually moved away from this position. From the mid-1990s, a small group of businessmen, known as the oligarchs, became increasingly powerful. They consolidated their power dramatically in the loans-for-shares operation in late 1995 and as a result of their support for Yeltsin's reelection campaign in 1996. They used this power to influence both the economic policy agenda, including the preparation of legislation, and the implementation of policy. They sponsored members of the Duma and even government ministers. ${ }^{5}$ They made special arrangements with the government about the amount of taxation that they would pay. They were not opposed to market-oriented reforms in principle and, indeed, provided a bulwark against a return to a planned, state-owned economy. But they sought to ensure that their own businesses were protected from competition and had favorable financial dealings with the government (through sales to government and, for enterprises with government stakes, dividend payments, as well as through privatization and tax deals). Once other businessmen

\footnotetext{
${ }^{4}$ Klyamkin and Shevtsova (1999) have written about Yeltsin's great weakness in practice, despite his considerable constitutional powers.

${ }^{5}$ For a short time, from August 1996 to March 1997, Vladimir Potanin, a leading oligarch, was first deputy prime minister with responsibility for economic policy.
} 
saw what the major oligarchs were able to get away with, they all tried to emulate them, further weakening the state. ${ }^{6}$

The lack of consensus in favor of liberal economic reforms within the Russian leadership and the weakness of the Russian state were the two most important reasons why economic reforms did not progress more smoothly, despite the stated policies of the government.

\section{B. IMF Policy Advice}

The IMF's basic view of the necessary economic reforms was that it was important to move as quickly as possible with all the key changes, especially macroeconomic stabilization, liberalization, and privatization. The IMF recognized that many reforms would take years to complete, especially the construction of the legal infrastructure for a market economy, privatization and restructuring of large enterprises, and the creation of a market system for banking and finance. ${ }^{7}$ But this was not seen as a reason for postponing the main stabilization and liberalization measures, with some specific exceptions, such as gradually rather than suddenly raising the prices of public utilities and housing rents and reducing export taxes on energy and other basic imports. ${ }^{8}$ Thus IMF views were similar to those of Russian reformers and many foreign observers. As a consequence, the IMF was often in the position of endorsing policies proposed by reformers with little need to push for major changes in them. ${ }^{9}$

Although, as noted in Section I, this paper does not attempt an analysis of the quality and relevance of IMF policy advice, a few brief comments regarding the case for rapid reforms may help to set the scene for the rest of the paper. ${ }^{10}$ First, the disintegration of the old central planning system had reached such an advanced stage by the end of 1991 that there was little scope for pursuing a gradual strategy in which the new system would be phased in as the old one was dismantled. Second, the experience of those transition countries, such as the Baltics, that were able to implement a strategy of rapid reform was that living standards rose from

\footnotetext{
${ }^{6}$ See Nagy (2000) and Graham (2002) for more discussion of the weak state. Nagy focused primarily on the implications for economic reforms and the economy.

${ }^{7}$ Camdessus (1992) noted that the process of basic economic transformation would take many years. Odling-Smee and Wolf (1994) classified reforms according to whether they could be undertaken over short-, medium-, or longer-term time horizons.

8 The earliest official statement of the IMF's views about economic reforms are in IMF and others (1990). See, especially, Chapter V (pages 16-19) for a discussion about the speed and sequencing of reforms.

${ }^{9}$ Vladimir Mau, a leading reformer, explained the situation as follows: "A good part of the "IMF conditions" were developed in Moscow, not Washington. Russian politicians are the ones who initiated many of these conditions" (Mau (2000) p. 108).

10 The case for a gradualist strategy as presented by a number of authors is discussed in Åslund (2002). See, especially, Chapter 3 on Strategic Policy Choices.
} 
their low point earlier and more rapidly than in slower reformers. The countries that sought to maintain many features of the old system, such as Belarus and Uzbekistan, appeared to avoid as sharp an initial fall in GDP as other transition countries, but are now growing more slowly and still face some potentially very disruptive reforms. ${ }^{11}$ Third, the many difficulties of the reform process in Russia, especially those stemming from the opposition from old vested interests and new powerful oligarchs, would not have been more manageable had the reforms been introduced more slowly. The underlying problems of the collapse of the old system and the weak state would still have presented major challenges. For these and other reasons that are discussed in more detail elsewhere, the IMF's view of the appropriate reform strategy has remained broadly unchanged despite the difficulties Russia has endured. ${ }^{12}$

In the early 1990s, IMF advice was directed primarily towards avoiding hyperinflation and bringing inflation down quickly to low levels, so as to create the conditions for the resumption of growth. In these years, IMF emphasized the necessity of tight monetary and fiscal policies to contain inflation. This contrasted with the alternative view, popular in some Russian circles, that more credit expansion was needed to stimulate output. In this view inflation was the result of the absence of competition, not excessive monetary growth. While the IMF was concerned in the early years about both monetary and fiscal policies being too loose, once inflation had been brought under control, by the end of 1995, it focused more sharply on fiscal policy. This reflected the difficulties that the Russian government met in attempting to tighten fiscal policy, difficulties that culminated in the financial crisis of August 1998. After 1999, with macroeconomic stability reestablished and the economy growing at a good rate, the IMF's policy advice included such issues as how to manage monetary policy in a situation of large increases in international reserves and medium-term fiscal policy in a world of fluctuating oil prices and revenues.

This summary of the broad policy issues on which the IMF gave advice cannot capture the full range and depth of the many detailed aspects of macroeconomic policy formulation and implementation on which the IMF gave advice and technical assistance. Missions from IMF headquarters and staff resident in Moscow discussed with Russian counterparts in the CBR, the ministry of finance, and other government departments all the relevant details, such as how to set monetary policy to achieve a desired reduction in inflation, the design of instruments for controlling the money supply, the creation of a treasury in the finance ministry, and the meaning and importance of quasi-fiscal deficits. (See the Annex for a

11 The experience of China and other Asian transition countries is not very relevant to Russia and other former Soviet area countries because political systems in the Asian countries did not collapse. More importantly, the Asian economies were largely agricultural, and the share of large industrial enterprises in total production and employment was much smaller than in Russia and other Soviet area economies. See Sachs and Wing Thye Woo (1994), Mau (2000), and Kalra and Sløk (2001).

${ }^{12}$ See Hernández-Catá (1995), Citrin (1995), Anderson, Citrin, and Lahiri (1995), OdlingSmee (1996), Fischer and Sahay (2000), Owen and Robinson (2003), and Owen (2004), for more detailed discussion of these issues by IMF staff. 
description of the channels of IMF advice.) Whereas the reformers were often familiar with the broad policy issues they discussed with the IMF, they and technicians in the CBR and government did not necessarily know how to give operational meaning to their policy choices, or how to handle many of the detailed issues that arose. The IMF played a major role in transferring knowledge about such issues, all within a context of market-oriented macroeconomic policies aimed at producing low inflation and a favorable environment for growth.

While the official policy was to request technical and financial assistance from the IMF, and many individual Russian officials benefited from discussions with IMF counterparts, it was not easy for Russians, individually or collectively, to seek and accept advice from IMF staff members. Russia saw itself as a strong, independent nation with centuries of history as a major European power and recent experience as a technically sophisticated world superpower. Many Russians, especially older and more nationalistic ones, felt that it was humiliating to have to negotiate with the IMF for loans and to adjust economic policies to IMF requirements. IMF staff tried to be sensitive to this need for country "ownership" of economic policies, which is an issue in the IMF's relations with all sovereign member states, albeit magnified in the case of Russia. But there was inevitably some tension in the relationship between the IMF and Russia arising from Russia's selfimage and history. ${ }^{13}$

The IMF's policy and technical advice focused on macroeconomic issues and the structural and institutional reforms in the monetary and fiscal areas needed to design and execute macroeconomic policy. But the IMF was fully aware that the major-and most difficultparts of the transition to a market economy were the structural and institutional reforms of the whole economic system. This was noted as early as April 1992 by Michel Camdessus, Managing Director of the IMF from 1987 to 2000, who put the "speedy adoption of a legal institutional framework" first out of five broad reform areas. ${ }^{14}$ Macroeconomic stabilization was the third reform area in his list. The IMF took every opportunity to emphasize, both in discussions with the authorities and in public, the importance of the broad structural and institutional reform agenda. A failure to make sufficient progress with structural and institutional reforms would not only threaten macroeconomic stability, but would also prevent the resumption of economic growth. An example of this was the initial response of many unreformed enterprises to the sharp changes in demand and relative prices at the beginning of the transition. Rather than make internal adjustments and seek new products or markets, as enterprises that operate under strict financial discipline in market economies

\footnotetext{
${ }^{13}$ Yevgeny Primakov, prime minister from September 1998 to May 1999 and previously a senior member of the Soviet foreign policy establishment, was representative of those who found it most difficult to accept the IMF's role in Russia. In his memoirs, he said that he was boiling inwardly when he thought that Gérard Bélanger, IMF mission chief in 1999-2002, was "moralizing" (Primakov, 2001). Earlier in a November 1998 meeting with Jorge Márquez-Ruarte, IMF mission chief in 1997-99, he had accused the IMF of dictating to Russia and acting like Bolsheviks.

${ }^{14}$ Camdessus (1992).
} 
would do, they sought credits, tax breaks, and subsidies from the authorities, thereby complicating the task of macroeconomic policy.

Although the IMF recognized the paramount importance of structural and institutional reforms, it was not in practice able to give much practical policy advice in these areas. This reflected its mandate to focus on macroeconomic issues, with other international financial institutions (especially the World Bank) focusing on the structural and institutional areas. ${ }^{15}$ Nevertheless, the IMF worked closely with the World Bank to ensure that the government included important structural reforms in its programs. The World Bank was responsible for the discussions with the government about the details of the reforms. The IMF's role was to assist in identifying broad reform priorities and to insist that key reforms were included in the programs before the IMF would agree to support them financially. This helped the government to obtain support, in turn, from the Duma and other groups and to explain its policies at home and abroad.

The high point of the IMF's involvement in advising on structural and institutional reforms was the preparation, with the authorities and the World Bank, of the government's mediumterm economic program in 1995-96. Many discussions took place and papers were prepared over the six or more months leading up to the approval of the program, and a loan under the Extended Fund Facility (EFF), by the IMF's Executive Board in March 1996. The outcome of this work was the structural reform agenda summarized in Box 1. The IMF's contribution was primarily in the banking, finance, and fiscal areas, although it also tried to keep up the momentum of efforts in other areas. In practice, with the exception of some critical measures in the fiscal area, the IMF did not subsequently insist on the implementation of the original structural agenda. The authorities made rather slow progress in most areas, which raises the question whether the whole effort was misconceived. The counterargument, which was the prevalent - although not the only_-view in the IMF at the time, was that a reform agenda like this one would strengthen the hand of reformers in government, and increase the likelihood that reforms would be implemented. With the benefit of hindsight, one can add that, although structural reforms may have been slow to get off the ground in the 1990s, the acceleration after 2000 probably owes something to the earlier preparations.

15 Thus the World Bank's Country Assistance Evaluation for Russia noted that the Bank, IMF, and EBRD were asked by their shareholders to work together to facilitate Russia's transition: "The Bank was entrusted with the responsibility of encouraging and overseeing structural reforms. ... A series of strategy documents established that, beyond its complementary assistance in support for IMF-funded stabilization efforts, the Bank's focus would be on helping build the institutions of a market economy, developing the private sector, and mitigating the social costs of transition" World Bank (2003) p. xi. 


\section{Box 1. Structural Reform Agenda, 1996-98}

Banking system: Conduct examinations of the financial condition of the largest banks; introduce legislation on bank bankruptcy; begin bank rehabilitation; improve transparency of banks disclosed financial information, including introduction of International Accounting Standards (IAS); strengthen contract enforcement; facilitate entry of foreign banks.

Payments system: Develop a strategy for improving the payments system; introduce same-day settlement for large transfers among the financial centers; improve the efficiency of clearing centers; and introduce electronic settlements.

Bank supervision: Introduce additional, tightened, and more transparent reporting requirements based on IAS; widen bank audits; introduce penalties for noncompliance with prudential requirements.

Capital markets: Introduce securities legislation; adopt minimum standards for market participants; amend the law on bankruptcy and the civil code to strengthen creditor rights.

Foreign trade: Reduce the average and maximum import tariff; remove export duties; eliminate duty exemptions; remove mandatory registration of export contracts; remove import quotas on alcohol; harmonize excise taxation of domestic and imported goods.

Budget system and process: Consolidate extrabudgetary expenditures and revenues; improve expenditure management, including through monitoring successive stages of the spending process with strengthened budgetary accounting; strengthen internal auditing.

Energy taxation and revenue measures: Improve efficiency and effectiveness of the tax system applicable to oil production; revise taxation system of gas and power sectors; increase revenues from remaining state ownership in the energy sector.

Intergovernmental fiscal relations: Redesign the tax sharing system; limit State Tax Service responsibilities to collecting taxes; conduct an overall evaluation of intergovernmental relations.

Agriculture: Introduce a land register and facilitate land registration; increase transferability of land; untie the provision of inputs from state procurement; introduce procedures for bankruptcy of agricultural enterprises; introduce a land tax to finance social services at the local government level; develop an agricultural tax strategy for inclusion in the federal budget; target transfers to the regions or specific activities to link them to reforms.

Urban land and real estate: Introduce a land cadastre; facilitate purchase of leased land; improve transparency of land use rights, strengthen loan collateral rights, and introduce mortgage legislation.

Privatization and corporate governance: Set targets for privatization revenues; improve information on enterprises to be privatized; use privatization receipts to clear tax arrears; apply uniform and transparent rules to cash privatizations; broaden monitoring and disclosure of financial information of enterprises.

Natural monopolies: Eliminate tax exemptions for natural monopolies; allow natural monopolies to discontinue services to nonpaying customers; improve governance and efficiency of each of the four natural monopolies (gas, electric power, telecommunications, and rail); prepare a restructuring/privatization plan for each natural monopoly; strengthen regulatory institutions to oversee tariff regulation; introduce and foster competition among competitive segments of the system.

Social safety net: Delink pension and unemployment benefits from the minimum wage; amend legislation to introduce a twotier pension system; strengthen payroll tax revenue collections through broadening the tax base; strengthen eligibility criteria for the pension system; conduct an assessment of the effectiveness of the social safety net in three poor regions; trim benefits of the employment fund, increase its centralized share and transfer its revenue collection activities to the State Tax Service; strengthen auditing of social funds; initiate a new pension law; introduce a basic poverty benefit; adopt a transparent cash management system for the pension fund; introduce a program of support for long-term unemployed based on the budgetary constraints of the employment fund.

Health care: Audit the medical insurance fund; define a package of minimum benefits in relation to resource availability at the regional and federal levels; offer a choice of health insurance companies and health service providers; introduce oversight and regulation of insurance companies.

Education: introduce a system of user fees and capitation formulas for the 1997 budget; facilitate entry of new educational institutions; develop an action plan for ensuring minimum standards for school achievement and testing; make the allocation of research funds competitive. 
It must be admitted that the IMF did not generally have a significant influence on structural and institutional reforms other than those related to the design and implementation of monetary and fiscal policies (e.g., the introduction of money market instruments, the design of the treasury, and tax administration). This partly reflected the staff's limited expertise and the IMF's macroeconomic mandate. More importantly, the IMF had to focus its efforts on macroeconomic, especially fiscal, issues during the difficult years of the 1990s, and had little leverage left to persuade the government to implement its structural reform program. If macroeconomic policies were being successfully implemented, the IMF was, in practice, usually unwilling to delay disbursements, because of problems on the structural side, other than problems with those measures, such as those related to revenue collection, that affected monetary or fiscal policy directly.

There were two prominent exceptions to this. First, in January 1997 the IMF delayed a disbursement because of delays in repealing a resolution introducing quotas on alcohol and vodka imports and in differentiating natural gas prices to reflect transportation costs. Second, in November 1999, a disbursement was delayed, and, in fact, was never made at all, ostensibly because the authorities did not fully implement various structural measures relating to the CBR's foreign subsidiaries and its internal accounting and control arrangements. As discussed later, the real reason for this delay was more complicated. These two cases notwithstanding, the Russian authorities understood that the IMF was unlikely to delay disbursements for reasons not directly connected to macroeconomic policy problems. Partly as a result of this, they gave lower priority to implementing the structural and institutional measures in their programs than to macroeconomic measures.

There was quite a contrast between the IMF's limited influence on structural and institutional reforms and the public perception in Russia and elsewhere that the IMF was responsible for policy advice in these areas and, indeed, for what actually did or did not happen. This perception was reasonable given that the programs that the IMF supported with loans, notably the 1996 program, had a large structural component, and that speeches by IMF leaders stressed the importance of structural reforms. The media focus on the drama of IMFRussia negotiations added to the image of the IMF having influence across a much wider range of policies than was the case. The role of the World Bank, the EBRD, and others who were actively involved in advising on structural and institutional reforms received less public attention. While a general perception that the IMF was responsible for advice and outcomes in the structural and institutional area was understandable, it is surprising that some people who knew what the IMF's role actually was have continued to hold the IMF accountable for problematic outcomes. ${ }^{16}$

\footnotetext{
${ }^{16}$ For example, Stiglitz (2002) has strongly criticized the IMF for insisting on rapid privitization, whatever the price, and without being concerned about whether market institutions, such as a competitive system, were in place first. This led, he argued, to IMF acquiescence in the loans-for-shares scheme and to corruption, state capture, and growing income inequalities. (See below for more on the loans-for-shares scheme.) As Chief Economist at the World Bank in 1997-2000, he knew that the World Bank rather than the IMF was in the lead in advising on these issues and that the IMF had little influence.
} 


\section{Influence of the G-7}

The transition of Russia from a planned to a market economy and the associated transition to a democracy was, of course, of great concern to the rest of the world, especially the major western countries. There was some discussion at the beginning of the 1990s about a so-called "Grand Bargain." This was the name given to the idea that the major western countries would give Russia large sums of money in exchange for deep and sustained economic reform efforts. ${ }^{17}$ The main problem with the Grand Bargain was that the western side was reluctant to mobilize and spend the large sums of money that were being suggested without evidence that major reforms were being undertaken. They were unwilling even to commit to the idea because of a deep skepticism about whether the Soviet Union and, subsequently, Russia really was ready to implement such reforms. Instead, they turned to the international financial institutions (IFIs), which had the capacity to apply conditionality to any lending, as well as significant sums of money.

By not providing large scale financial support themselves to Russia, the G-7 were effectively assigning two tasks to the IFIs that were sometimes contradictory. ${ }^{18}$ First, the IFIs were expected to perform their usual function of lending on the basis of economic policies or projects that met the normal standards of the institutions. In insisting that Russia had to agree its economic policies with the IMF, the G-7 caused Russia to take the IMF's views more seriously than it might otherwise have done. Second, the G-7 sometimes wanted the IFIs to lend in order to show support for the government (or President Yeltsin), even at times when economic policies or projects were not up to the standard normally required by the IFIs. The advocates in G-7 countries of the two tasks were sometimes split between institutions, with the finance ministry being most concerned that the normal standards of the IFIs should be upheld, and the foreign ministry wishing to show support for Russia (or not, according to the circumstances) based on broader political and bilateral circumstances. The president or prime minister would synthesize these views. The distinction was clear in the United States where the Treasury, to which the U.S. Executive Director of the IMF reports, supported strict IMF conditionality, and the U.S. State Department focused on the political and bilateral issues. The White House generally supported the Treasury position, although sometimes it allowed its impatience to see more IMF lending to overcome Treasury concerns about weak Russian policies. One incident in December 1993 illustrates this: Vice-President Gore complained in

Similarly, Lopez-Claros (2002), who represented the IMF in Moscow in 1992-95, deplored the fact that the IMF did not stop the loans-for-shares scheme.

${ }^{17}$ See Allison and Yavlinsky (1991).

${ }^{18}$ In fact, quite large sums of money were provided by the G-7, although most of it was tied to particular imports (suppliers' credits) or expenditures (e.g., housing for troops returning from Germany), or was debt relief. In 1992 and 1993, all bilateral creditors provided a total of US\$36 billion of financial assistance, with the G-7 accounting for the bulk of it (Citrin and Lahiri, 1995, Table 7.5). 
public in Moscow about IMF policies being too tough, to the annoyance of the Treasury, which supported the IMF's attempts to tighten macroeconomic policies (see Box 2).

\section{Box 2. U.S. Attitudes to the IMF after the 1993 Duma Elections}

The U.S. political leadership was concerned about the outcome of the Duma elections in December 1993, in which the nationalists and communists emerged with a majority, and liberal, prowestern groups were in the minority. On a visit to Moscow a few days after the elections, Vice President Gore said in a press conference alongside Chernomyrdin that the IMF had been "slow to recognize some of the hardships that are caused by some of the conditions that have been overly insisted upon in the past." According to Talbot (2003), the U.S. Deputy Secretary of State who was accompanying Gore, the latter already had some sympathy for the view that the IMF was too tough on Russia dating back at least to a discussion in Washington in September 1993 between Chernomyrdin, who asked for IMF leniency, and Treasury undersecretary Summers, who defended IMF conditionality. Talbot himself appeared to call for a softer line when he said in a press briefing later in December that the administration wanted to promote "less shock and more therapy." Both the Russian reformers and the U.S. Treasury disliked what Gore and Talbot said because it undercut the efforts of the reformers, notably First Deputy Prime Minister Gaidar and Deputy Prime Minister and Finance Minister Fedorov, to persuade the government, especially Chernomyrdin, to pursue tight monetary and fiscal policies in 1994. ${ }^{1 /}$ In February 1994, the U.S. Senate Committee on Banking held hearings on the impact of IMF and World Bank policies on the Russian economy. Witnesses included Jeffrey Sachs, who argued that the IMF should permit a bigger fiscal deficit that would be financed by issuing bonds and more borrowing abroad, and also Marshall Goldman, Peter Reddaway, and Jude Wanniski.

It is difficult to say how great an impact these public statements by, and discussions among, U.S. political leaders had on IMF/Russia relations. On the one hand, the U.S. Treasury continued to support the IMF's attempt to persuade the Russians to follow strict monetary and fiscal policies. On the other hand, the IMF leadership (and the U.S. Treasury) was aware that the political mood in Washington and other G-7 capitals could swing so much that the good intentions of finance ministries to support the IMF could be swept aside. Camdessus was therefore more willing to settle, during his visit to Moscow in March 1994, for an economic program that was less strict than he would have liked, to preempt any undue pressure from the G-7. Perhaps more importantly, the U.S. statements produced a hardening of the Russian position. One aspect of this was the resignation in January 1994 of both Gaidar and Fedorov from the government, which chose to pursue the less strict of the macroeconomic policy options under consideration. Gaidar (1997) believed that the U.S. criticism of the IMF for excessive tightness weakened its ability to put its weight behind those, including himself, who were arguing for the radical disinflation option.

${ }^{1 /}$ In his recent memoirs, Talbot (2003) noted that he infuriated "both Russian liberals and my colleagues at Treasury" and regretted the language he used, while also arguing that the hardships accompanying reforms were backfiring against the reformers.

This situation was unsatisfactory for both the Russians and the IMF. Russian governments thought that the West should be prepared to make available large sums of money without difficult policy conditions attached. This was a small price to pay for ensuring that Russia never returned to communism or confrontation with the West. The Russians resented the need to negotiate with the IMF and the delay this involved. The IMF was unhappy because it feared that the political concerns of the G-7 to make IMF money available to Russia, even when the normal economic policy conditions were not met, might cause the G-7 to push the 
IMF to lend with insufficiently strong conditionality. ${ }^{19}$ Although this never happened in an overt way, an atmosphere was sometimes created, for example at the end of 1993 as described in Box 2 and 1996-98 as discussed in Section III, in which the IMF felt that it should err on the side of supporting weak policies rather than interrupt disbursements altogether. The Russians understood the situation and sometimes saw negotiations with the IMF as a charade since they believed that the G-7 would ultimately insist that the IMF should go ahead with the loans.

Among the G-7 countries, the United States effectively determined the collective position. It was unusual for other countries to initiate approaches different from the U.S. one, or to strongly oppose U.S. initiatives, except on matters relating to Russia's debt to G-7 countries. Here Germany, by far the largest creditor, was able to modify U.S. policy positions, which tended to favor more generous debt relief than Germany could accept. The Russian authorities understood the preeminent position of the United States and frequently sought U.S. support to put pressure on the IMF. ${ }^{20}$

To sum up, during the years before the 1998 crisis, while the G-7 helped to create an important role for the IMF in Russia, its political and bilateral interests at the same time caused a weakening of the IMF's influence. Many IMF staff members often felt that it would have been better for the Russian economy and for the consistency of the IMF's position across its member countries if it had insisted on more ambitious policies, especially fiscal policy, before agreeing to lend, and on fuller implementation of agreed policies before resuming lending after a break due to poor implementation. A stronger position would also have embraced some conditions on the effective implementation of structural measures. Managing Director Michel Camdessus and First Deputy Managing Director Stanley Fischer, who were keen to avoid any formal proposals from the G-7, were more prepared to make disbursements on the basis of the best promises and prior actions that the Russians could make. Apart from the G-7 angle, they, together with some staff members, also believed that the IMF's ability to influence Russian economic policies was greater when there was an active dialogue without lengthy interruptions of lending. The Executive Board was split, with some members doubting the wisdom of continuing to support weak Russian policies, although this rarely led to a rupture of the Board's traditional consensus. After 1998, and especially after the newspaper stories suggesting money laundering scandals and the renewed

${ }^{19}$ IMF here means not only the management and staff, but also many members of the Executive Board, albeit a minority, who did not like to see the majority pushing the Board in this direction.

${ }^{20}$ Talbot (2003) described several occasions when Russian leaders pressed U.S. leaders to ensure IMF financial assistance. Primakov (2001) commented that the keys to a Russia-IMF agreement were "obviously in the hands of the US." He also noted that Germany's Chancellor Schröder gave a positive response to President Yeltsin's request for early IMF finance and France's President Chirac promised Primakov "to fix things up with Camdessus." 
fighting in Chechnya in 1999, the G-7 took a much harder line on IMF lending. This too was reflected in the IMF's behavior.

\section{WHERE THE IMF MADE A DIFFERENCE}

This section begins with an overview of the IMF's involvement in macroeconomic policy in the 1990s. This is followed by a discussion of the IMF's impact in the fiscal, monetary, and exchange rate policy areas. The treatment is selective, focusing on only a few key issues.

\section{A. Overview}

By the time the IMF had its first discussions with the new Russian government in November 1991, Gaidar and his team already had a clear idea of the economic reforms they wanted to introduce. ${ }^{21}$ IMF staff teams met with the new government almost from the beginning and sought to provide technical advice, especially on the importance and modalities of designing a consistent macroeconomic policy framework with a quantified program of monetary and fiscal measures to achieve specific macroeconomic objectives. In February 1992, IMF staff assisted the Russian authorities with the preparation of a policy program that the government and CBR then published. The program did not, however, contain a quantified monetary program because of a lack of consensus between the government and CBR, problems arising from other countries' use of the ruble, and inadequate CBR databases. Subsequent discussions in May, June, and July 1992 about a more detailed program that the IMF could support with financial assistance, after Russia became a member on June 1, built further on this first program. However, the policies themselves were essentially those chosen by the authorities. At the time of the February program, the IMF had little substantive disagreement with the Russians. But in the summer negotiations, the government was already moving toward less tight monetary and fiscal policies in response to pressures from the political opposition to support production. The IMF staff opposed this, but in the end the IMF decided to support the program sought by the Russians in the interest of providing some financial assistance, as desired (and as had been promised) by the G-7. ${ }^{22}$

From about April 1992 onwards, political opposition to the government's strict monetary and fiscal policies grew sharply. The IMF was criticized by reformers in the government and their western supporters for not providing financial assistance on a larger scale and much earlier than the first $\$ 1$ billion that was approved by the Executive Board on August 5, 1992 (Table 1). The main reason for the timetable was that time was needed to make Russia a

${ }^{21}$ Gaidar (1999) explains the debates among the reform team.

${ }^{22}$ One example of a difference of view on which the IMF gave way to the Russians was the oil price. The IMF argued for a larger increase in the domestic price of oil than the Russians were willing to implement, on the grounds that this was a move toward market pricing, and that it would allow the government to collect more revenues from the oil sector and achieve a more ambitious target for the fiscal deficit. 
member of the IMF and also to agree on an economic program with the authorities. ${ }^{23}$ The IMF limited the amount of the loan because Russia did not have complete control over its monetary policy, because of the pursuit of uncoordinated monetary policies by all the countries that used the ruble. The IMF had, in May, sought to make the ruble area work by brokering an agreement between ruble area countries, but Russia was not willing to share power and the agreement never materialized. Russia would have preferred the IMF to have acted decisively to bring the ruble area to an end. As explained elsewhere (Odling-Smee and Pastor, 2002), the IMF, as a cooperative institution, could not do this as long as some members wanted to retain the area, and it was too early to conclude that a successful ruble area was politically impossible. Gaidar (1997 and 1999), recognizing the constraints on the speed at which the IMF could move and its rules-based lending policies, has argued that the IMF was not the right instrument to handle the large-scale political problem of Russia's transition in 1992, when the situation was so unpredictable. But, in the absence of major, untied, G-7 financial assistance, the IMF was the main instrument available.

Table 1. IMF Lending to Russia, by Type of Arrangement (In millions of SDRs)

\begin{tabular}{llrr}
\hline & \multicolumn{1}{c}{$\begin{array}{c}\text { IMF Board } \\
\text { approval date }\end{array}$} & $\begin{array}{c}\text { Amount } \\
\text { approved }\end{array}$ & $\begin{array}{c}\text { Amount } \\
\text { disbursed }\end{array}$ \\
Type of Arrangement & & August 5, 1992 & 719 \\
Stand-by Arrangement (First Credit Tranche) & June 30, 1993 & 1,078 & 719 \\
Systemic Transformation Facility (First Tranche) & March 22, 1994 & 1,078 & 1,078 \\
Systemic Transformation Facility (Second Tranche) & April 11, 1995 & 4,313 & 4,313 \\
Stand-By Arrangement & March 26, 1996 & 6,901 & 5,105 \\
Extended Fund Facility & July 20, 1998 & 1,248 & - \\
Extended Fund Facility Augmentation & July 20, 1998 & 3,992 & 675 \\
Supplemental Reserve Facility & July 20, 1998 & 2,157 & 2,157 \\
Compensation and Contingency Financing Facility & July 28, 1999 & 3,300 & 471 \\
Stand-By Arrangement & & 24,786 & 15,596 \\
Total & & & \\
\hline
\end{tabular}

The period from mid-1992 until end-1994 was one of serious conflict between reformers and their opponents, both inside and outside the government. The outcome was that macroeconomic policies were less tight than the reformers would have liked, as they were forced to bow to pressures from interest groups that sought more CBR credits and budget subsidies. The IMF encouraged the authorities to implement reasonably tight monetary and fiscal policies, and the annual programs agreed in the early months of 1993 and 1994, which were supported by loans under the new Systemic Transformation Facility (STF), were in line

${ }^{23}$ Following an accelerated mechanism for admitting new members, Russia joined the IMF on June 1, 1992. Difficulties in agreeing on monetary policy and some other issues delayed agreement on an economic program until early July, and the Executive Board meeting to approve the first loan was held on August 5. 
with this. ${ }^{24}$ The Russian authorities were in agreement with these programs, mainly because they had persuaded the IMF that anything more ambitious in terms of reducing inflation and the budget deficit - however desirable - would not be feasible. As noted above, at the time of the negotiations for the 1994 program, the U.S. authorities were openly expressing concerns that the IMF was being too tough (see Box 2). This stance weakened the IMF's negotiating position, which was already more fluid than in normal situations because precedents for the strength of programs to be backed by STF loans had not yet been set. While this produced a less ambitious disinflation program for 1994 than the reformers and the IMF would have liked, it is unlikely that the outcome for the year would have been much different because the pressures for looser monetary and fiscal policies that built up during the year, including unbudgeted expenditures on agriculture and the Northern Territories, would still have been there.

It is possible to see the 1992-94 period as one during which the reformers, supported by the IMF, were gradually able to move towards macroeconomic stabilization. Dubinin (1995), who was acting finance minister from early 1994 until October 1994, talked about a hardening of financial policies in a phased manner, to allow the continuation of some inflationary financing until enterprises were able to adjust to the new market conditions. A more accurate description might be that the reformers were doing the best they could to stabilize the economy, winning battles whenever possible and otherwise retreating. The 21 percent collapse in the ruble exchange rate on Black Tuesday (October 11, 1994) was a direct consequence of the loose monetary policies. Dubinin (1995) noted that this signified the failure of the gradualist strategy. It certainly led to a significant change in attitude among Russian leaders outside the reformist group. Chernomyrdin, in particular, was determined to pursue policies that would avoid a repetition of such an event.

The failure of the gradualist or (depending on one's point of view) ad hoc approach to macroeconomic stabilization was brought home to people not only by Black Tuesday but also by the continued decline in output. The argument of supporters of loose monetary policy that it was needed to protect output was shown to be incorrect. These facts, as much as the IMF's repeated recommendations for tightening monetary and fiscal policies, were mainly behind the tighter policies implemented in 1995.

The new leadership set about preparing an economic program for $1995 .^{25}$ The IMF worked closely with them and supported the program with a one-year Stand-By Arrangement (SBA) approved by the Executive Board on April 11, 1995. The macroeconomic stabilization objectives were more demanding than in earlier years with monthly inflation targeted to fall

\footnotetext{
${ }^{24}$ The STF was introduced by the IMF in April 1993 to enable it to lend to countries that were making the transition from centrally planned to market economies, before they were able to implement strong macroeconomic stabilization and reform programs.

${ }^{25}$ Mrs. Tatiana Paramonova was appointed acting chairman of the CBR in October 1994 after Gerashchenko resigned. Chubais, who was already a deputy prime minister, took over responsibility for macroeconomic policy issues from Alexander Shokhin, who also resigned.
} 
to 1 percent by July and then to stay there, and the general government deficit set to be $61 / 2$ percent of GDP (Figure 1). No direct CBR lending to the budget was permitted after the first quarter. More importantly, the program was successfully implemented, although inflation did not fall quite as much as planned (Figure 2). All the quantitative targets were met in nine out of twelve of the months of the program and the full IMF loan, about US $\$ 61 / 2$ billion, was disbursed (see Table 2). ${ }^{26}$

Figure 1. General Government Deficit

(In percent of actual GDP)

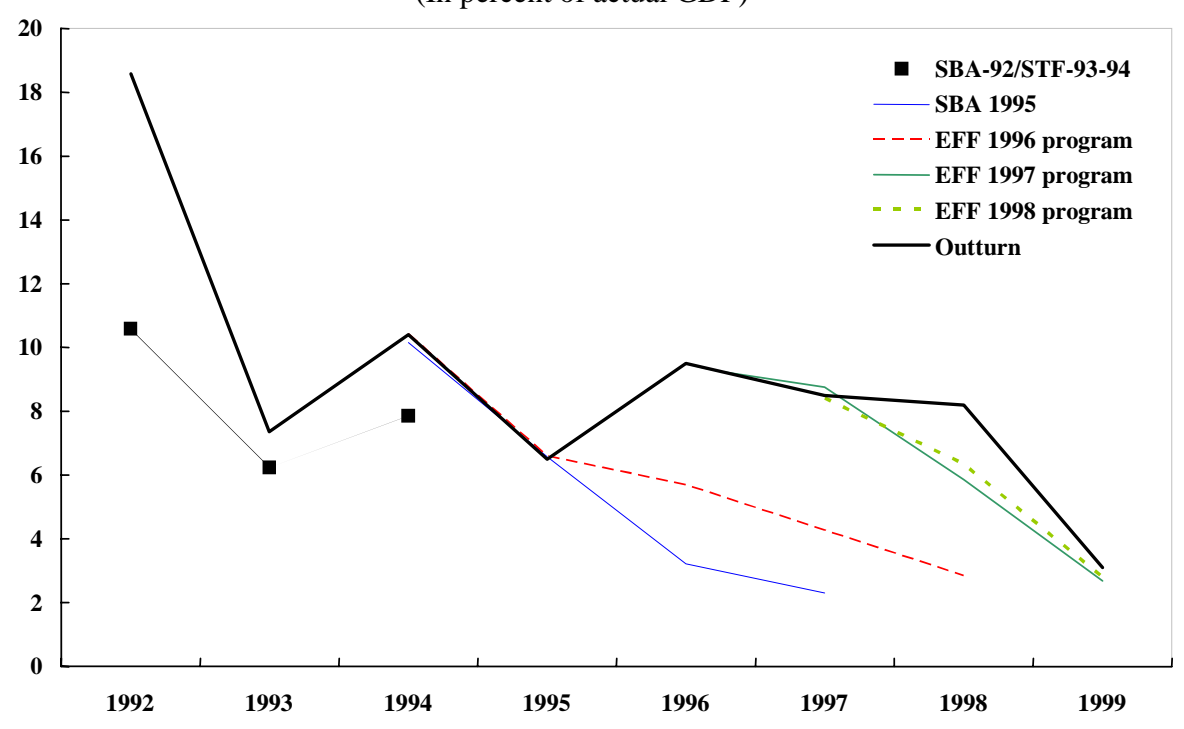

Figure 2. CPI Inflation

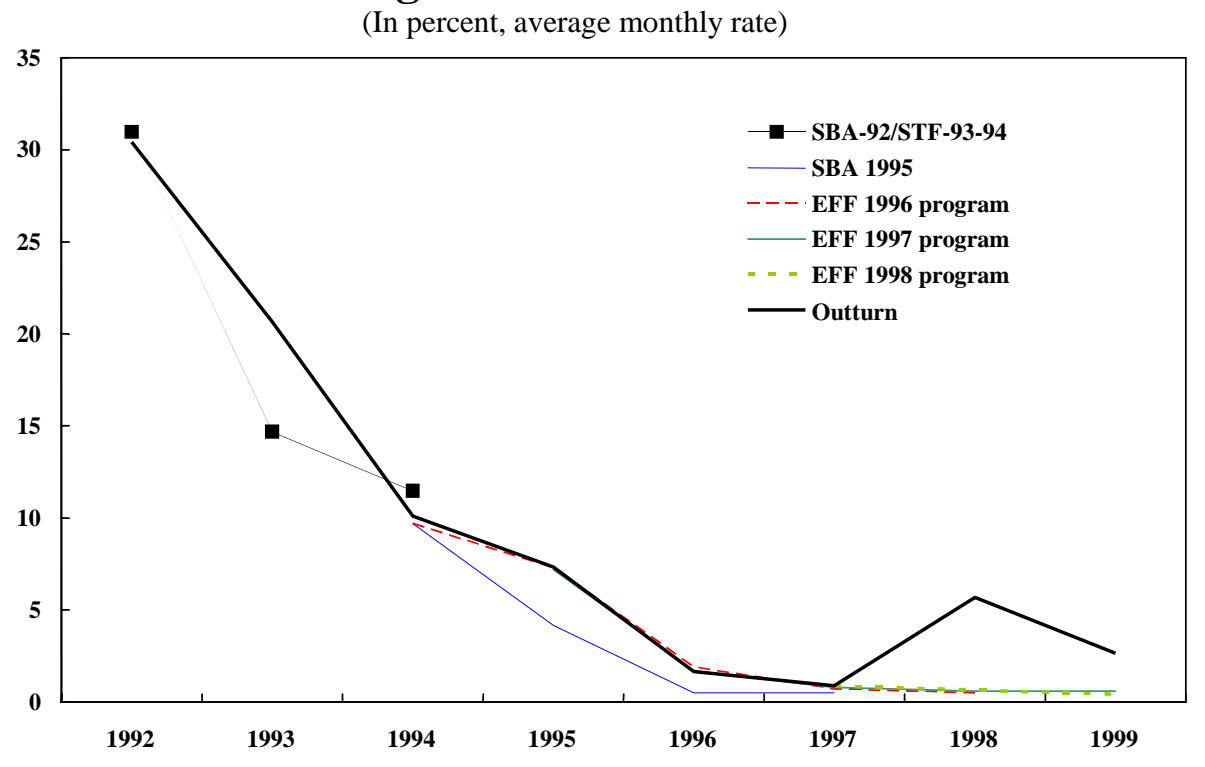

${ }^{26}$ The IMF monitored progress on a monthly basis as described later. 
Table 2. IMF Lending to Russia, by Year

\begin{tabular}{|c|c|c|c|}
\hline Year & Disbursements & Repayments & $\begin{array}{l}\text { Outstanding } \\
\text { (end of year) }\end{array}$ \\
\hline \multicolumn{4}{|c|}{ (In millions of SDRs) } \\
\hline 1992 & 719 & - & 719 \\
\hline 1993 & 1,078 & - & 1,797 \\
\hline 1994 & 1,078 & - & 2,876 \\
\hline 1995 & 3,594 & - & 6,470 \\
\hline 1996 & 2,588 & 359 & 8,698 \\
\hline 1997 & 1,467 & 360 & 9,806 \\
\hline 1998 & 4,600 & 674 & 13,732 \\
\hline 1999 & 471 & 3,101 & 11,102 \\
\hline 2000 & - & 2,189 & 8,913 \\
\hline 2001 & - & 2,998 & 5,915 \\
\hline 2002 & - & 1,148 & 4,767 \\
\hline 2003 & - & 1,356 & 3,411 \\
\hline \multicolumn{4}{|c|}{ (In billions of U.S. dollars) $^{1 /}$} \\
\hline 1992 & 1.0 & - & 1.0 \\
\hline 1993 & 1.5 & - & 2.5 \\
\hline 1994 & 1.5 & - & 4.2 \\
\hline 1995 & 5.5 & - & 9.6 \\
\hline 1996 & 3.8 & 0.5 & 12.5 \\
\hline 1997 & 2.0 & 0.5 & 13.2 \\
\hline 1998 & 6.2 & 0.9 & 19.3 \\
\hline 1999 & 0.6 & 4.2 & 15.2 \\
\hline 2000 & - & 2.9 & 11.6 \\
\hline 2001 & - & 3.8 & 7.4 \\
\hline 2002 & - & 1.5 & 6.5 \\
\hline 2003 & - & 1.9 & 5.1 \\
\hline
\end{tabular}

${ }^{1 /}$ Converted from SDRs at the exchange rate at the time (annual average and end-year).

One of the consequences of the successful monetary tightening was the strong appreciation of the nominal exchange rate beginning in April 1995. ${ }^{27}$ The authorities were concerned about this, partly because of its impact on competitiveness and the real value of the population's foreign currency savings, but also because of fears that there could be a sharp reversal with economic and political consequences even more severe than those following Black Tuesday. They therefore introduced an exchange rate corridor in July, in order to contain appreciation and any subsequent depreciation pressures.

${ }^{27}$ With inflation still high, the real appreciation was especially rapid. 
Although the actual fiscal deficit in 1995 was in line with the target, revenues and expenditures were not as high as originally intended. As in most years in the 1990s, revenues were below the projected level mainly because well-connected enterprises had been able to reduce their tax liabilities, either by obtaining formal tax exemptions or by informal arrangements. The government responded by holding expenditures below budgeted levels, which subsequently created serious problems. First, by allowing wage and pension arrears to build up, the government only postponed the problem until 1996, when special loans had to be raised to pay off the arrears (in part because it was an election year). Second, the fact that the government was not paying its bills-for procurement of goods and services, as well as wages and pensions - was a major reason for the financial indiscipline throughout the economy. It contributed to the withholding of tax revenues by taxpayers who were not themselves being paid by the government, and to the growth of the pernicious practice of offsets. $^{28}$

The loans-for-shares scheme introduced in 1995 also had lasting adverse economic consequences. ${ }^{29}$ Starting in May 1995, the IMF expressed concerns about the lack of transparency and the unsatisfactory arrangements for competitive bidding. The scheme, as it was endorsed by the president in October, looked more reasonable on paper, but there remained scope for collusion, nontransparency, and asset-stripping. IMF staff warned about this in October and, in December, criticized the implementation of the scheme (see Owen, 2004, for more details). ${ }^{30}$ However, the IMF did not consider postponing disbursements on this account for the general reasons relating to structural reforms noted earlier, namely the IMF's macroeconomic mandate and modest expertise in structural issues, and the need to focus its limited influence on macroeconomic policy issues. ${ }^{31}$

Despite these problems with arrears and loans-for-shares (and others not discussed here), the IMF judged the 1995 program to have been broadly successful as a major step toward macroeconomic stability. From the middle of 1995, the IMF staff therefore discussed with

${ }^{28}$ Offsets were arrangements between the government and individual enterprises whereby the government's unpaid obligations to an enterprise and an equivalent amount of the enterprise's unpaid tax liabilities were cancelled. They encouraged enterprises not to pay their taxes in the expectation of future offsets. The IMF pushed for many years for the practice to be banned.

${ }^{29}$ Under this scheme, banks controlled by oligarchs made loans to the government on the security of attractive but undervalued state assets (e.g., oil enterprises), then took possession of the assets when the government subsequently failed to repay the loans.

${ }^{30}$ These concerns and criticisms were voiced to the authorities directly and to all IMF members in papers for the Executive Board.

${ }^{31}$ Given the very strong political wind behind the scheme, it is anyway doubtful whether the IMF, or the World Bank for that matter, could have had much influence on its actual implementation. See Freeland (2000) for a full account that emphasizes the political context. 
the authorities a medium-term economic program that the IMF could support with a three year loan under the Extended Fund Facility (EFF). The program that was eventually approved when the EFF was considered by the Executive Board in March 1996, envisaged further disinflation and reductions in the general government deficit to 4 percent, 3 percent, and 2 percent in 1996, 1997 and 1998, respectively (see Figure 1, where the deficits are shown as a percent of actual GDP, as now estimated, rather than the GDP as estimated at the time). However, performance under the EFF was not as good as under the SBA.

The fiscal situation deteriorated sharply during 1996. Partly this was the direct consequence of the build-up to the presidential elections, which brought promises of more expenditure from the president and an increased capital outflow. To keep the exchange rate within the band, interest rates had to be raised sharply, which added significantly to the government's interest expenditures. Moreover, the revenue shortfalls worsened, for two main reasons. The first was the reduced tax discipline as a result of the government's own expenditure arrears, noted above. Second, the powerful oligarchs, who helped to secure Yeltsin's reelection, reduced their tax payments. It was no coincidence that nearly all the main enterprises with tax arrears at the end of 1996 were oil or gas companies.

New hope was kindled by Yeltsin's hard hitting State of the Nation speech in March 1997 and his appointment of Anatoly Chubais and Boris Nemtsov as first deputy prime ministers. This appeared to signal a willingness to tackle the oligarchs and restore some of the authority of the state. In a speech in Moscow in April 1997, Camdessus (1997) strongly urged the authorities to establish the proper role for the state in a market economy, including collecting taxes, meeting the government's own financial obligations, and avoiding excessively close relationships with large enterprises. But tax collection did not improve as the intense struggle between oligarchs and government and among the oligarchs themselves progressed. The Emergency Tax Commission that had been set up in October 1996 was not effective at increasing revenues.

The effects of the Asian crisis began to be felt in Russia towards the end of 1997. Contagion led to a large outflow of capital in November, to which the authorities responded by tightening monetary policy. During the following months, the oil price collapsed with adverse consequences for Russia's balance of payments and government revenues.

The IMF's advice in the first half of 1998 was to tighten monetary policy and introduce new fiscal measures to deal with the growing fiscal gap. The former worked in January, but the very high interest rates in May did not contain the loss of international reserves. While the authorities recognized the need for further fiscal measures, they were paralyzed by the unexpected dismissal on March 23 of Chernomyrdin as prime minister, and the delay until Sergei Kiriyenko was approved on April 24. With confidence not restored in financial markets after the May crisis, calls for more drastic measures were heard, including devaluation, refinancing of government debt to extend maturities, and a massive external loan. The IMF's room for maneuver was narrowed by the announcement, by President Clinton's office on May 31, that the United States endorsed additional financial support from the international financial institutions to promote stability and structural reforms. During the months that followed until the crisis in August, the IMF was focused on attempting to strengthen Russia's fiscal policy, knowing that the government was weak and could not 
deliver very much. The key event here was the approval on July 20 by the Executive Board of a major loan (US $\$ 4.8$ billion) in support of a new package of fiscal and other measures, many of which would not take effect until January 1999. The aim of this loan was to provide Russia with additional reserves so that it could manage any short-term outflows, until such time as confidence in financial markets was restored. Unfortunately, after a temporary improvement in July, confidence continued to weaken in August and drastic measures, such as those announced on August 17, became inevitable.

After a failed effort to avert a financial crisis, it always appears that the attempt was a mistake. The increase in Russia's international reserves after the new loan was disbursed was reversed in the subsequent weeks as financial players converted rubles into dollars. ${ }^{32}$ But it is important to assess the situation as it appeared at the time. Judged from the point of view of the balance of payments, which was not in "fundamental disequilibrium," the exchange rate was not obviously overvalued. ${ }^{33}$ The government under Kiriyenko was firmly committed to trying to bring the fiscal situation under control, although the absence of strong support from the Duma was a matter of some concern. ${ }^{34}$ There was, therefore, a reasonable chance that confidence would return to financial markets and the crisis would be averted. As the government clearly wanted to take the chance, and was prepared to take the measures necessary to strengthen policies, especially in the fiscal area, the IMF chose to support it, although there were naturally some misgivings among both Executive Directors and IMF staff. $^{35}$

Following the crisis, the IMF's main concern was that the new leadership of the government and the CBR should not move towards more inflationary policies, thereby losing the degree of macroeconomic stability that had been achieved with difficulty over the previous few

${ }^{32}$ Some months later, a story emerged that the money had been stolen and ended up in the bank accounts of people close to the president and government leaders. There was no truth to this: the documents purporting to prove it were forged, and a detailed audit of the CBR's reserves found that they had been used to support the ruble, as was intended they should be, if needed.

33 The boost to growth from the devaluation might suggest that an earlier devaluation would have led to an earlier recovery. But, as discussed below and in Owen (2004), this conclusion is not clear-cut because higher inflation would have worked in the opposite direction. Even if it is partly correct, it does not in itself mean that the exchange rate was overvalued.

${ }^{34}$ The Duma did in fact pass a large number of measures in a few days in mid-July, but rejected two key measures, one to increase personal income tax revenues and the other to restore balance to the Pension Fund.

${ }^{35}$ The comments of Summers (2001) and Fischer (2001) on Kharas, Pinto and Ulatov (2001) contain an excellent exposition of the case for supporting the government's policies at that time. 
years. ${ }^{36}$ In fact, the authorities pursued reasonably tight monetary and fiscal policies, after a short injection of liquidity to the banking system that was motivated mainly by the need to protect the payments system. Although the IMF made no further disbursements under the $\mathrm{EFF}$, the authorities hoped to reach an agreement with the IMF that would lead to disbursements, and this gave the IMF some influence. But more important was the message of the crisis, that the fiscal deficit must be kept under control if problems were to be avoided. In addition, of course, the government's inability to borrow abroad and limited scope at home imposed a much tighter limit on the fiscal deficit than before the crisis.

With macroeconomic policies being reasonably sound in the winter of 1998-99, the IMF was able to reach agreement with the authorities in the spring of 1999 on a program to be supported by a new Stand-By Arrangement. Following delays caused by, among other things, a change of government and the need to investigate accounting irregularities in the CBR dating back to 1996, the Executive Board approved the SBA in July 1999. Macroeconomic policy performance was generally in line with the program, helped by higher oil prices and the recovery of growth in the economy. But the appearance of press stories about corruption and misuse of public funds led the IMF, encouraged by the G-7, to ask for various structural improvements in accounting and control practices in the CBR, including its relationship with its subsidiaries. These were not fully implemented, which gave the IMF a reason for not making the disbursement under the SBA that was due in November, as noted earlier.

However, attitudes in major western countries towards helping Russia had hardened because of the press stories and the start of the second Chechen war. As a result, the G-7 made clear to IMF management that they did not favor a disbursement at that time, and the IMF adopted an unusually strict position toward the nonimplementation of structural measures. Thus the IMF's relations with Russia were tested (and strained, because the government partly blamed the messenger) by the G-7's sharply cooler attitude, after many years of being under stress because of G-7 pressures in the opposite direction.

As the macroeconomic situation, especially the balance of payments, continued to improve during 2000-2003, it became apparent that there was no need for the IMF to lend to Russia. ${ }^{37}$ Moreover, most government leaders were eager to see an end to negotiations over economic policies. The relationship between the IMF and the authorities, therefore, changed from one involving negotiations and detailed monitoring by the IMF to one in which the IMF was a more detached observer and advisor, as is the case with the IMF's relations with other major countries. The absence of negotiations made for an easier dialogue between the IMF and the authorities but also released the latter from the obligation to agree its economic policies with the IMF. Despite this, IMF policy and technical advice was generally welcomed and had some impact on policymaking and implementation.

\footnotetext{
${ }^{36}$ In September, Yevgeny Primakov became prime minister and appointed Yuri Maslyukov as first deputy prime minister for economic policy. Mikhail Zadornov remained as finance minister. Gerashchenko returned as CBR chairman.

${ }^{37}$ Developments since 1998 are discussed in detail in Owen and Robinson (2003).
} 
A final point for this section relates to the development during the course of the 1990s of the authorities' understanding about macroeconomic policy and how to implement it. Whereas in the early and mid-1990s, the IMF's messages about the importance of macroeconomic stability and how to achieve it were understood and accepted by relatively few reformers in the government and CBR, by the early 2000s they were fully accepted by most important policymakers, including leaders of the Duma. The IMF itself contributed to this development through the continuous dialogue its staff and management had with counterparts at every level. This included the highest levels where Camdessus' personal relationship with Chernomyrdin was a factor in the latter's coming to trust IMF advice about macroeconomic policy. ${ }^{38}$ The spread of knowledge was assisted by the gradual change of generations, with some of the younger reformers of the early and mid-1990s who were most open to modern macroeconomic analysis coming to hold senior positions.

But, given the deep differences of view within Russia about economic policy in the transition to the market, the competition for political and economic power, and the suspicions inherited from Soviet times about foreign advisors, IMF advice alone was not enough to change things. The experience of the 1990s was also a necessary part of the learning process, especially the failure of the attempts in 1992-94 to stimulate output through expansionary monetary and fiscal policies, the crises of Black Tuesday (October 1994) and August 1998, and the coincidence of the post-1998 recovery with the tightening of fiscal policy. But the importance of real world experience does not diminish the major contribution that the IMF made to the transformation of the authorities' understanding of macroeconomic policy issues and implementation.

\section{B. Fiscal Policy}

Macroeconomic stabilization required a reduction in the fiscal deficit from the high levels of the early 1990s. This was generally agreed by both the reformers in the government and the IMF. However, good intentions to reduce the deficit were thwarted in most years before 1999 by unanticipated shortfalls in revenue, and in some years by excessive spending (see Figures 1 and 3). The failure to reduce the deficit decisively was, of course, the single most important cause of the 1998 financial crisis. This section first discusses the IMF's role in the reduction of the deficit and related issues, especially the shortfalls in revenues. It then briefly considers the IMF's role with respect to social expenditures, oil export duty, and the liberalization of the treasury bill market.

${ }^{38}$ There was, however, a downside to this in Camdessus' increased willingness to accept Chernomyrdin's pleas for continued disbursements when conditions had not been met. 
Figure 3. Federal Revenues

(In percent of actual GDP)

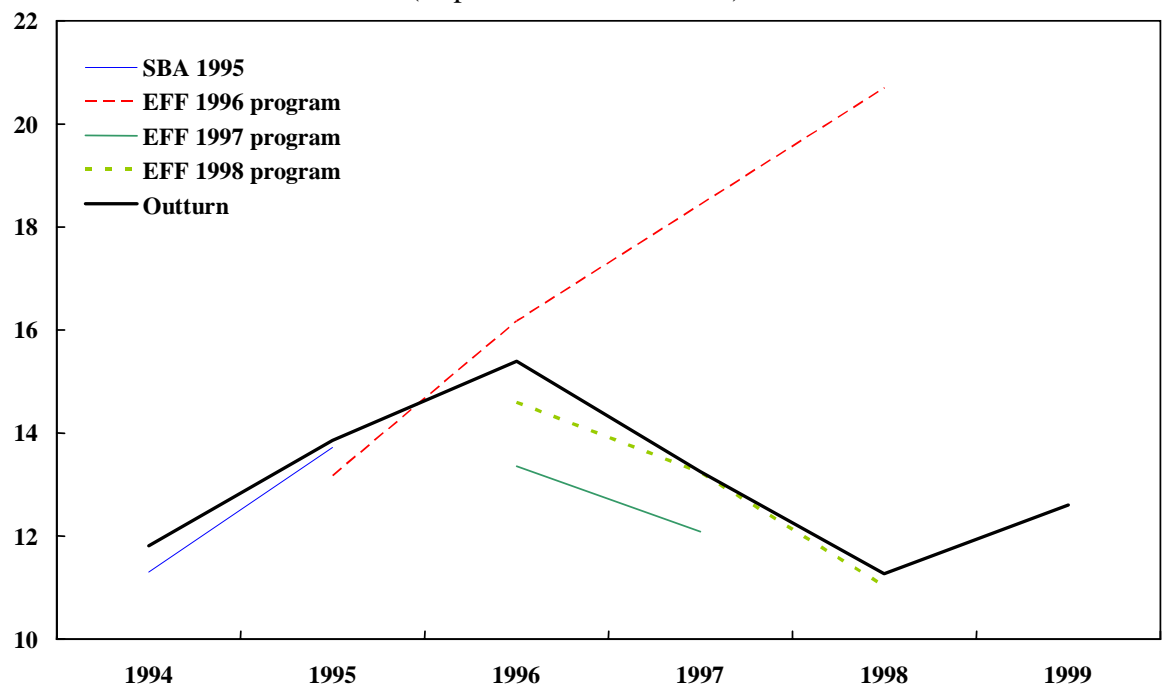

Impact of the IMF

A distinction should be made between the planned deficit and the actual outturn. Both the reformers and the IMF sought a similar path for the reduction in the deficit. In the absence of the IMF, it is unlikely that the reformers would have been able to resist the pressure from others in government and the Duma to plan for a bigger deficit, especially in 1995 and 1996. In some years, for example 1995, the IMF was able to agree easily with the government's plans for the deficit, but it had to argue for additional measures to raise revenues or cut expenditures because the revenue projections were too optimistic, and the planned deficit was unattainable without additional measures. ${ }^{39}$ In 1997, the IMF had little influence on the planned deficits. It accepted the authorities' argument that only a small reduction from the high outturn of 1996 was possible during the following year or two and that major improvements had to be postponed.

The planned deficit was one thing; what actually happened was quite another. The IMF's impact on the implementation of fiscal policy and, hence, on the short-term fiscal deficit was rather weak. As Figure 1 shows, the failure to keep the actual deficit in line with the planned deficit, except in 1995 and 1997, was the main reason why deficits remained so high before 1999. Most of the overshooting was the result of revenue shortfalls; some came from spending overruns. Both of these were in most cases under the control of the authorities, with some important exceptions, such as the higher interest expenditures before the presidential elections in June 1996 and after the Asian crisis in 1997, and the lower oil revenues in 1998.

\footnotetext{
${ }^{39}$ It was common for the Duma to increase expenditures in the draft budget and to "finance" the increase by arbitrarily raising projected revenues.
} 
The IMF attempted to influence the implementation of fiscal policy by monitoring it during the course of the year and urging the authorities to take corrective measures if necessary. Such encouragement had no teeth in 1992-1994 because the IMF made only one disbursement in each year and had little leverage over developments in the later months of the year. For two years, beginning with the Stand-By Arrangement (approved in April 1995), there was a formal system of monthly disbursements linked to monthly reviews of progress towards the targets of the program. While this enabled the IMF to check almost continuously on policy implementation, it also made it more difficult to resist proposals from the authorities to change the next month's targets because of insufficient time to take measures to meet them. For this reason, and to encourage the authorities to take more responsibility, in 1997 and 1998 the IMF switched to the more normal quarterly disbursements linked to quarterly reviews.

The IMF's ultimate lever for influencing fiscal policy implementation was its disbursements. A number of disbursements between the middle of 1996 and the middle of 1998 were delayed because of insufficient progress towards the targets or inadequate corrective measures, mostly but not always in the fiscal area. The slippages in disbursements were only minor in the second half of 1996, but became larger in the first half of 1997 (see Table 3). There was an improvement in the summer months of 1997, but this was followed by a deterioration later in the year and into 1998, as large slippages reemerged. Associated with the delays was the easing of targets, both those that had already been missed and future ones that could not be achieved (see Table 3). Although, as noted above, some of the easing of targets reflected factors outside the government's control, most of the cases, especially in the fiscal area, were because the authorities had not implemented the agreed policies in full. The summary in Table 4 does not distinguish between cases within and outside the government's control, but a careful analysis indicates that weak implementation was often the main factor. ${ }^{40}$ The IMF's hope at the time that its close monitoring would lead to an improvement in implementation, especially of fiscal policy, was, therefore, only partly realized during the 1996-98 EFF period.

What was the IMF's impact on the level of revenues? The IMF certainly tried through various means to prevent the shortfalls in revenues. It provided extensive technical assistance on tax administration, and posted a senior tax administration expert in the State Tax Service to assist the authorities. ${ }^{41}$ It set targets for revenue collections as conditions for disbursements of IMF loans, starting in August 1996. It frequently insisted on the introduction of new tax measures to increase either the effective tax rates or to improve tax administration, before agreeing to disbursements. As shown in Table 4, most reviews under the EFF involved new

\footnotetext{
${ }^{40}$ A full list of the reasons why some reviews were delayed, and the measures that were taken to enable reviews to be completed, is available on request from the author: jodlingsmee@juno.com

${ }^{41}$ Richard Highfield, previously a Second Commissioner of the Australian Tax Office, was an advisor to the Ministry of Taxation from September 1997 to August 1999.
} 
Table 3. Delays in Disbursements Under the Extended Fund Facility (in millions of SDRs)

\begin{tabular}{|c|c|c|c|c|}
\hline \multicolumn{2}{|c|}{ Expected Disbursements } & \multicolumn{3}{|c|}{ Actual Disbursements } \\
\hline Earliest date & Amount & Date & Amount & $\begin{array}{l}\text { Review on which } \\
\text { Disbursement Based }\end{array}$ \\
\hline \multicolumn{5}{|c|}{ A. Schedule approved on March 26, 1996} \\
\hline March 26, 1996 & 233.6 & March 29 & 233.6 & Approval of EFF \\
\hline April 15, 1996 & 233.6 & May 3 & 233.6 & First monthly \\
\hline May 15, 1996 & 233.6 & June 10 & 233.6 & First quarterly \\
\hline June 15,1996 & 233.6 & June 28 & 233.6 & Third monthly \\
\hline July 15,1996 & 233.6 & August 26 & 233.6 & Fourth monthly \\
\hline August 15, 1996 & 233.6 & September 18 & 233.6 & Second quarterly \\
\hline September 15,1996 & 233.6 & October 11 & 233.6 & Sixth monthly \\
\hline October 15 & 233.6 & & & \\
\hline November 15,1996 & 233.6 & December 18 & 233.6 & Third quarterly \\
\hline December 15, 1996 & 233.6 & & & \\
\hline January 15,1997 & 233.6 & February 12 & 467.3 & Eighth monthly \\
\hline February 15, 1997 & 233.6 & & & \\
\hline May 15, 1997 and later & 4,097.6 & & & \\
\hline \multicolumn{5}{|c|}{ B. Revised schedule approved on May 16, 1997} \\
\hline May 16, 1997 & 500.0 & May 21 & 500.0 & Second annual \\
\hline August 1, 1997 & 500.0 & September 8 & 500.0 & Fifth quarterly \\
\hline November 1,1997 & 500.0 & January 13 & 500.0 & Sixth quarterly \\
\hline February 1, 1998 & 500.0 & June 30 & 500.0 & Seventh quarterly \\
\hline May 16, 1998 and later & $2,564.7$ & & & \\
\hline \multicolumn{5}{|c|}{ C. Revised schedule approved on July $20,1998^{2 /}$} \\
\hline July 20, 1998 & 768.4 & July 22 & 768.4 & Emergency review \\
\hline $\begin{array}{l}\text { September } 15 \text { and later } \\
\text { dates } 1 /\end{array}$ & $1,796.3$ & & & \\
\hline
\end{tabular}

\footnotetext{
${ }^{1 /}$ The detailed schedules for these disbursements are not shown because they were replaced by revised schedules in the first two cases and no further disbursements were made in the third case.

${ }^{2 /}$ The amounts in this panel refer only to those committed under the original EFF. The additional amounts approved on July 20 under the EFF augmentation, the Supplemental Reserve Facility and the Compensation and Contingency Financing Facility are shown in Table 1. The actual disbursements under the three facilities were all made on July 22.
} 
Table 4. Reviews Under the Extended Fund Facility

\begin{tabular}{|c|c|c|c|c|}
\hline $\begin{array}{l}\text { Date of Board } \\
\text { Meeting }\end{array}$ & Review & Delay & Easing of Targets & Fiscal Measures \\
\hline March 26, 1996 & Approval of EFF & & & \\
\hline April 29, 1996 & First monthly & On time & $\begin{array}{l}\text { Fiscal deficits increased from April to enable } \\
\text { payment of wage arrears using new foreign loans; } \\
\text { deficits reduced towards end of } 1996 \text { so that annual } \\
\text { deficit target unchanged. }\end{array}$ & \\
\hline June 5, 1996 & First quarterly & On time & $\begin{array}{l}\text { Fiscal deficits increased from May because of higher } \\
\text { interest payments than expected. }\end{array}$ & \\
\hline June 24, 1996 & Third monthly & On time & May target for international reserves missed. & \\
\hline August 21, 1996 & Fourth monthly & $\begin{array}{l}\text { Delayed by one } \\
\text { month }\end{array}$ & $\begin{array}{l}\text { June targets for international reserves, net domestic } \\
\text { assets, net credit to government and federal } \\
\text { government deficit missed. Fiscal deficits from July } \\
\text { onwards raised because of weak revenue collections } \\
\text { and higher interest payments. Targets for } \\
\text { international reserves, net domestic assets, and net } \\
\text { credit to government eased to reflect higher growth } \\
\text { in nominal GDP and money demand. }\end{array}$ & $\begin{array}{l}\text { Measures taken to } \\
\text { strengthen revenues. }\end{array}$ \\
\hline September 13, 1996 & Second quarterly & On time & & \\
\hline October 8, 1996 & Sixth monthly & On time & & \\
\hline December 13, 1996 & Third quarterly & On time & $\begin{array}{l}\text { September and October targets for international } \\
\text { reserves, tax revenues and fiscal deficits missed. } \\
\text { November and subsequent targets for tax revenues, } \\
\text { fiscal deficits and reserves eased. Targets for net } \\
\text { domestic assets and net credit to government } \\
\text { tightened. }\end{array}$ & $\begin{array}{l}\text { Measures taken to } \\
\text { strengthen tax collection. } \\
\text { Major program of } \\
\text { revenue measures } \\
\text { developed. }\end{array}$ \\
\hline February 7, 1997 & Eighth monthly & $\begin{array}{l}\text { Delayed by two } \\
\text { months, but two } \\
\text { monthly } \\
\text { disbursements made } \\
\text { together }\end{array}$ & $\begin{array}{l}\text { No further easing: delay caused by the delays in } \\
\text { October-December } 1996 \text {. }\end{array}$ & \\
\hline May 16, 1997 & $\begin{array}{l}\text { Second annual } \\
\text { Ninth monthly }\end{array}$ & $\begin{array}{l}\text { On time but two } \\
\text { monthly } \\
\text { disbursements } \\
\text { missed }\end{array}$ & $\begin{array}{l}\text { January targets for most things missed, but March } \\
\text { targets hit. New targets set for second year. }\end{array}$ & $\begin{array}{l}\text { Measures taken to } \\
\text { strengthen tax revenues. }\end{array}$ \\
\hline September 3, 1997 & Fifth quarterly & On time & $\begin{array}{l}\text { June target for tax revenues missed by a small } \\
\text { amount. Credit targets tightened and reserves targets } \\
\text { raised for next two quarters. }\end{array}$ & \\
\hline January 8,1998 & Sixth quarterly & $\begin{array}{l}\text { Delayed by } 1-2 \\
\text { months }\end{array}$ & $\begin{array}{l}\text { September targets for international reserves and tax } \\
\text { revenues missed. Targets for international reserves, } \\
\text { tax revenues and credit growth eased for the fourth } \\
\text { quarter of } 1997 \text { and subsequent quarters. }\end{array}$ & $\begin{array}{l}\text { Measures taken to } \\
\text { strengthen tax collection. }\end{array}$ \\
\hline June 25, 1998 & $\begin{array}{l}\text { Third annual and } \\
\text { seventh quarterly }\end{array}$ & $\begin{array}{l}\text { Seventh quarterly } \\
\text { delayed by } 4 \text { months }\end{array}$ & $\begin{array}{l}\text { March targets for tax revenues and fiscal deficits } \\
\text { missed. Delays in implementing revenue reform } \\
\text { measures. }\end{array}$ & $\begin{array}{l}\text { Major program of tax and } \\
\text { expenditure measures } \\
\text { initiated. }\end{array}$ \\
\hline July 20, 1998 & $\begin{array}{l}\text { Emergency review, } \\
\text { with enhanced } \\
\text { commitments and } \\
\text { disbursements }\end{array}$ & Not applicable & & $\begin{array}{l}\text { Major program of } \\
\text { measures, mostly in the } \\
\text { fiscal area, launched. }\end{array}$ \\
\hline
\end{tabular}


tax measures, ranging widely from short-term fixes such as collecting tax arrears from specific debtors to fundamental reforms of the tax system. ${ }^{42}$ Despite all this activity, in a broader sense the IMF failed to have much of an impact on revenues which continued to fall short of targets until 1999.

\section{Assessment}

A superficial reading of the impact of the IMF on the fiscal deficit might suggest that the IMF did not have a major impact. The IMF was pushing for a substantial reduction in the deficit from the very high levels at the beginning of the 1990s, and some reduction was achieved. But the reduction was much less than either the IMF recommended or the government announced that it would bring about. Strong vested interests prevented weak governments from delivering on their commitments: taxes were not paid and unbudgeted expenditures were extracted from the government. The result of the failure to bring the fiscal deficit down was the August 1998 financial crisis, which could have been avoided if the fiscal situation had been under better control. ${ }^{43}$

Despite what the large deficits of the 1990s and the 1998 crisis suggest, the IMF was not without some influence. First, the government wanted to continue to qualify for IMF disbursements and, therefore, tried harder, albeit with rather modest results (except in 1995), to bring the deficit down below what it would have been in the absence of the IMF. The IMF helped to tilt the internal argument toward reformers who were pushing for more fiscal consolidation. Also, despite the disappointing overall outcome, many of the specific measures taken to enable Russia to continue to qualify for disbursements were good reform measures with long-term benefits. Second, the extensive discussions between the government and the IMF about fiscal (and monetary) policy issues led over time to there being a strong cadre within government that was able to articulate the case for a restrained fiscal policy in public and in private, and design an appropriate policy. Third, IMF advice and technical assistance contributed to many improvements in budget procedures, tax policy, and tax administration that made it easier to design and execute the budget as planned. As shown in more detail in the Annex, technical assistance in the fiscal area was concentrated on tax

${ }^{42}$ A full list of the revenue measures is available on request from the author: jodlingsmee@juno.com. The wide scope of the measures reflected the fact that many things needed to be put right, but also uncertainty about what the underlying reasons for poor tax collections were. Sometimes the problem seemed to be that the weak government was not able to force strong enterprises to pay their taxes; at other times the inadequacies of the tax administration system seemed to be the problem. The government urged the IMF not to insist on higher tax rates when the taxes due at existing rates were not being collected, but they did not themselves solve the collection problem. The sharp improvement in tax collections after 1998, as the economy grew, suggests that tax evasion rather than the tax administration system had been the main problem before 1998 .

${ }^{43}$ Hernández-Catá warned as early as the beginning of 1995 that the continuation of a strategy of large budget deficits was dangerous (see Hernández-Catá, 1995, p. 121). 
administration and the creation of the treasury, although there was also assistance on tax policy, public expenditure management, the social sector, and other issues. The impact of such assistance built up gradually over time, as administrative systems were reformed and increasing numbers of Russian officials learned the new ways of doing things. In the case of tax policy reform, major changes did not come until 2001 under President Putin. The seeds of some components of this reform had been sown earlier, partly by the IMF and other technical assistance advisors. The IMF staff had opposed other components, however, notably the move to a flat rate personal income tax, which, although desirable on structural grounds, had seemed to the staff to carry the risk of a temporary loss of revenue.

Would the IMF's influence on fiscal performance have been greater if it had postponed disbursements more often in response to missed targets? Consider first the accumulation of arrears as a by-product of the successful reduction of the deficit in 1995. The IMF was aware at the time of their adverse consequences, although perhaps did not envisage the full scale of the pending nonpayments problems that were partly caused by government arrears. ${ }^{44}$ But it was so relieved that good progress had been made toward macroeconomic stability that it did not aggressively challenge the manner in which it had been achieved. Had it done so, for example by postponing some disbursements in 1995 until revenues were raised or expenditures cut in a more economically sensible and socially acceptable way, future problems might have been diminished, although at the price of less progress in reducing the deficit and inflation.

Turning next to the missed targets for the deficit and/or revenues, especially between the middle of 1996 and the middle of 1998, when major taxpayers were able to make arrangements with the government to pay less than their full liabilities, there were some postponements in disbursements, but they were fairly short (see Table 3). At the time, the IMF generally believed that the chances of implementing the fiscal policy envisaged in the program were greater if postponements were not too frequent or prolonged. In the latter case, the relationship between the IMF and the authorities would become strained; the authorities would be less, rather than more, inclined to follow the IMF's advice; and the position of those reformers in government who shared the IMF's views would be weakened. These were years when the government appeared to be especially weak. Yeltsin was frequently sick and not exercising strong leadership. The oligarchs were confident of their power vis-à-vis the state and were manipulating the law or worse in order to add to their wealth. ${ }^{45}$ Under these circumstances, the G-7 favored engagement with Russia by the IMF as a way of adding some weight to those in government who were struggling to bring the fiscal situation under control. As noted above, the IMF was not impervious to the views of the G-7. But it should be added that the management of the IMF itself believed that close engagement with the Russians,

${ }^{44}$ See Cheasty and Davis (1996).

${ }^{45}$ A very senior representative of one of the biggest oil and banking groups told the author in November 1997 that the current period of asset grabbing would only last a few more years, and that after that his company would have to start earning money in the usual way of western companies. 
with continuous dialogue about economic programs and the next IMF disbursement, effected some improvements in policies and avoided major reversals, which could have been very disruptive. Given the importance of Russia in the region and the world, it was thought to be worth the risk to the IMF's reputation and finances to persist with the engagement.

The alternative view was that the government would be strengthened in its relations with recalcitrant taxpayers and others if it was deprived of IMF backing, especially financial support. ${ }^{46}$ This view was held by some reformers in Russia, notably Boris Fedorov and Andrei Illarionov. ${ }^{47}$ It was increasingly held by some in the IMF, both Executive Directors and staff. Changes in Russia, such as the appointment of Anatoly Chubais and Boris Nemtsov as first deputy prime ministers in March 1997, gave rise to new hope that the fiscal problems would be solved and held the growing disillusionment in the IMF at bay. The very large disbursement of US $\$ 4.8$ billion in July 1998 was seen by the IMF leadership as the last chance for Russia. When it did not succeed in restoring confidence, there could be no question of new disbursements without a major strengthening of the fiscal position.

We can now conclude this discussion of whether a firmer policy by the IMF, with less willingness to continue disbursing funds in the face of continued fiscal slippages, would have been better. A tougher line, with more interruptions to disbursements and less IMF money to finance deficits, might have had some impact on the behavior of recalcitrant taxpayers and the Duma majority that was opposed to the government's policy, although these groups were very powerful and were focused on improving their financial and political positions at the expense of the weak state. It might also have led to a crisis occurring well before August 1998, and perhaps being less damaging than the 1998 one was. Taking account of what we now know, including the cathartic effect of the crisis, it now seems that it would have been better for economic reforms in Russia, and for the IMF, if the IMF had taken a tougher line in 1996-98. It is, of course, much easier to say this now than at the time, when the possibility of economic collapse, or at least economic policy going seriously wrong, had the IMF not been actively lending, was still very real.

\footnotetext{
${ }^{46}$ An example of an occasion when the IMF's flexibility weakened the efforts of some in government to persuade taxpayers that they were serious about strengthening tax collection was an incident in December 1997. Chubais was trying to use the Emergency Tax Commission to seize the assets of two delinquent taxpayers. Chernomyrdin wanted to take a more lenient line with the two companies and urged Camdessus to agree with him while promising to improve tax collections. Camdessus took him at his word and decided that the IMF should not insist on specific actions by the Emergency Tax Commission as the prior actions for disbursing the next installment of the EFF. This had wider ramifications for other taxpayers' assessment of the government's willingness to tackle evasion.

${ }^{47}$ Boris Federov had been Deputy Prime Minister and Finance Minister in 1993, and Andrei Illarionov, who was an economic advisor to Prime Minister Chernomyrdin in the early 1990s, became President Putin's advisor in 2000.
} 


\section{Social Expenditures}

One of the major casualties of the failure to bring fiscal policy under control before 1999 was the social sector. The health and education sectors were starved of funds in the budget. Moreover, even the meager budgeted amounts for the social sector were often not made available, as resources were sequestered during the year and bills-including for wages and pensions-were not paid. Overall standards of living and general well-being for those who could not afford to pay out of their own pockets for health and education services were severely reduced as a result. The social safety net still consisted primarily of heavily subsidized prices, that were being raised over time, for housing and related services and for privileged groups, rather than income transfers based on need. Should the IMF have tried harder to protect social expenditure?

Some reduction in the real value of social sector expenditures was inevitable because of the decline in GDP. A further reduction would have been justified, if reforms had introduced more private financing of and charges for health, education, and other social services in a structured way. But, although there was a willingness in principle to introduce private financing and charging, the necessary structural reforms for this and for the overall reduction in the size of the sector were never undertaken in a comprehensive way. As a result, the adverse impact on living standards of the deterioration of the social sector was greater than it need have been.

The IMF's view from the beginning of the transition was that a strong social safety net was critically important and Camdessus frequently referred to that in his speeches. ${ }^{48}$ The IMF provided technical assistance on ways of targeting the social safety net on the most vulnerable groups instead of continuing with expensive subsidies that held down the cost of housing, utilities, and services for everyone. ${ }^{49}$ The IMF also encouraged the government to include various social protection measures in its programs. ${ }^{50}$ Reforms to social safety nets featured prominently in the government's program in 1992 and again in the 1996 EFFsupported program.

In practice, however, little effort was made to reform the social sector or to protect social expenditures from general fiscal tightness. This reflected the government's priorities against the background of its weakness in the face of strong taxpayers who were able to avoid paying their full obligations. Despite its concerns about this situation, the IMF did not push hard for

${ }^{48}$ In summarizing the desirable reform strategy, Camdessus (1992) gave equal billing to social security and to structural reforms and macroeconomic stabilization. He said that "the need for adequate social safety nets is greatest when society is undergoing far-reaching upheavals, as it is now." See also Camdessus (1994) and (1997).

49 The main lines of IMF advice are summarized in IMF (1995) and Chu and Gupta (1996).

${ }^{50}$ The IMF was not qualified to advise on the health and education sectors. The World Bank was active in these areas. 
higher social expenditures or the reform of the social safety net. It never made shortfalls in these areas a reason for delaying disbursements or a major sticking point in program negotiations. The Russians knew this: in the exception that proved the rule, they were surprised by the intensity of Camdessus' concern in 1999 to limit the large cuts in real wages and pensions that were being planned by the government as part of the adjustment to the 1998 crisis. ${ }^{51}$ But, in general, the IMF felt that it could not, against a background of weak revenues, insist on achieving both a satisfactory overall fiscal balance and the protection of social expenditures. ${ }^{52}$

\section{Specific Fiscal Issues}

There are two specific fiscal issues where the IMF made a difference and where, with hindsight, it made a mistake. ${ }^{53}$ The first was the abolition of oil export duty, which the IMF insisted, against the advice of the authorities, should be a prior action for the approval of the EFF in March 1996. This was seen as a major step in a program that had been running for a few years to remove all taxes and restrictions on exports. It was to be accompanied by an increase in excise duties on oil and oil products. As it turned out, the enforcement of the higher excise duties proved difficult as they were much easier to evade than the export duty. Export duties were reintroduced after the 1998 crisis. Given the importance of collecting as much revenue as possible in the 1996-98 period, it would have been better to have postponed the abolition of export duty on oil until the excise tax collection system and the government's authority were stronger.

Second, the IMF supported the government's wish to liberalize access to the treasury bill market by foreign investors in 1996. The government's intention was to reduce interest rates by opening up the market. The IMF was sympathetic to this view, and more generally to the liberalization of capital markets. There was also strong support from the G-7, especially the United States, for the same reasons. However, the CBR was opposed to this measure because they feared the possible volatility of external capital flows. The IMF pressed for liberalization, and in early 1997 the CBR agreed to a phased program of liberalization to be completed in January 1998. This added a significant element to the total financial market volatility that culminated in the August 1998 crisis, although, because of the behavior of domestic investors, the crisis would not have been avoided had the liberalization not occurred. $^{54}$

${ }^{51}$ Primakov complained to Camdessus about being outflanked on the left.

${ }^{52}$ Some people, for example Lopez-Claros (2002), have argued that the IMF's failure to protect the social safety net while allowing the oligarchs to minimize tax payments was a major mistake because it undermined support for reforms.

${ }^{53}$ See Owen (2004) for a more detailed discussion of these issues.

${ }^{54}$ While the IMF appeared to play an important role in bringing this about, some government officials and observers have argued that, if the IMF had not pressed, then the government would itself have insisted on the liberalization. 


\section{Monetary Policy}

Monetary policy in the 1990s falls into two periods: 1992-1994, when the reformers were struggling with others to bring about tighter monetary policy, and 1995-99, when the reformers had largely won the battle and monetary policy was mostly under control. Inflation was high in the first period and low (in single digits in 1996-97) in the second period, apart from the blip caused by the 1998 crisis (see Figures 4 and 5).

Figure 4: Inflation

(In percent, m-o-m change in $\mathrm{CPI}$ )

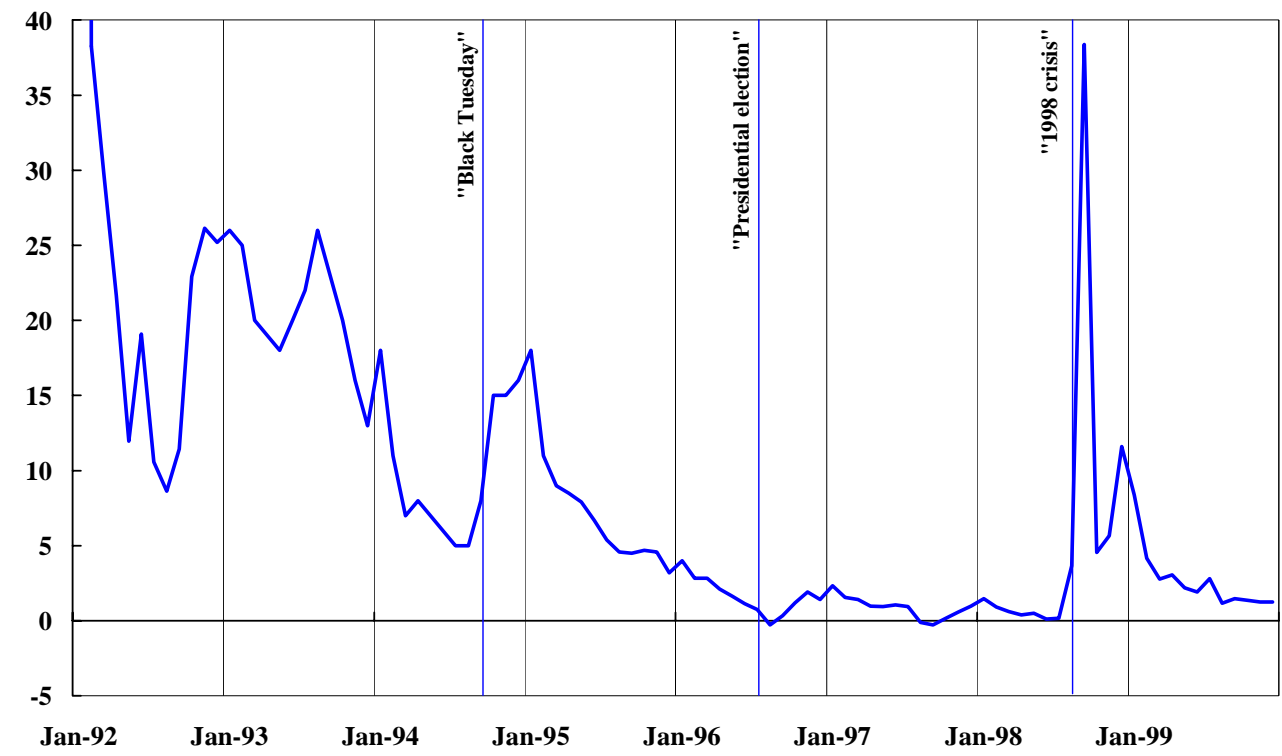

Figure 5: Inflation and Money

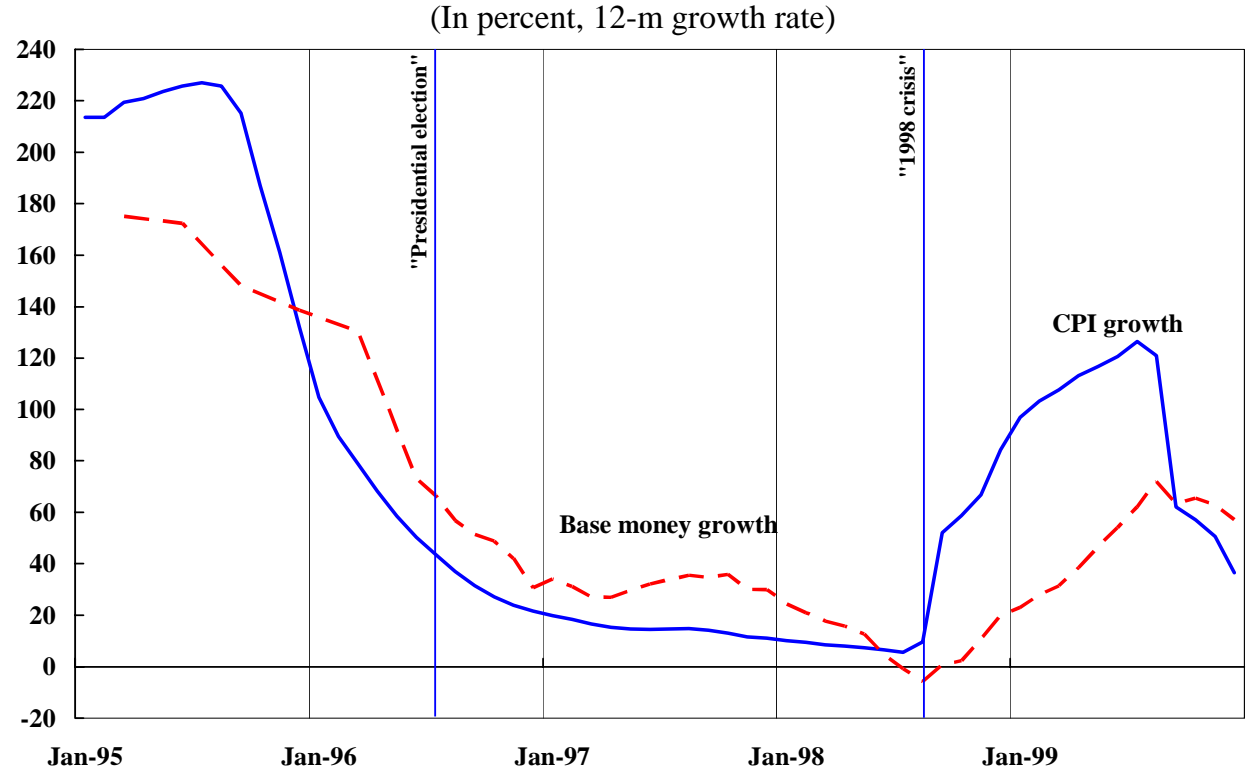


The efforts of the IMF were devoted in the first period to persuading the authorities that inflation was a serious problem, and that it could and should be tackled by tightening monetary policy. Technical assistance was provided to the CBR to strengthen its ability to plan and execute monetary policy. There was only limited understanding, except among reformers, that inflation was caused by loose monetary policy and excessive credit expansion. Various alternative views could be found, including that inflation was caused by price liberalization, the high degree of monopolization of the economy, or other market imperfections. There were also concerns that tightening monetary policy would reduce output growth rather than inflation. The IMF was actively engaged in countering these arguments, drawing on experience in other countries. ${ }^{55}$ It was helped by events, especially the continuation of high inflation well past the initial price liberalization, the failure of output to respond positively to the rapid credit expansion in the summers of 1992 and 1993 (and 1994), and the rise in inflation after the monetary expansion in the third quarter of 1994 and Black Tuesday in October. In turn, the IMF's arguments helped the reformers in their internal discussions.

Although the effect built up only slowly, by 1995 the IMF had had a significant influence on the authorities' views of the role of monetary policy and inflation. The IMF also had an influence on the measures by means of which monetary policy was tightened. For example, the program that was agreed with the IMF in mid-1993 included, at the IMF's suggestion, a rule for tying the CBR's bank lending rate to a market rate, which, when implemented together with a reduction in monetary credit growth, produced a sharp rise in the lending rate to a positive real level. The 1995 program targeted a major reduction in monthly inflation to $1 \%$ in July to be achieved by tightening monetary policy, and the government and the CBR endorsed it. While they might not have done so had they not been shocked by Black Tuesday, which led, among other things, to reformers taking leading positions in the government and CBR, the IMF also had an impact. The implementation of the program was made difficult by the unexpected capital inflows, which, in the absence of adequate sterilization instruments, caused excessive monetary growth in the middle of the year, and inflation remained above the target path. The IMF worked closely with the authorities during the year (there were monthly missions) on corrective measures to deal with the situation.

From 1995 onwards, the IMF's influence was less on major themes, such as tightening monetary policy to produce a big reduction in inflation, and more on the details of setting and implementing monetary policy. The continuous dialogue between IMF staff and the authorities about issues such as how to respond to inflows (1995 and 1997) and outflows (1996 and 1998) of international reserves, how and how much to sterilize changes in reserves, and how to keep credit growth in the economy within the targeted range was the channel for a major transfer of knowledge and experience from the IMF to the authorities.

55 This paragraph is based on Hernández-Catá (1995), who provides further details. 


\section{Exchange Rate Policy}

This section discusses the impact of the IMF on exchange rate policy at three critical stages: the liberalization of the exchange system in 1992, the introduction of the corridor in 1995, and the decision to maintain the pegged rate regime right up to August 1998.

The liberalization of the exchange system was one of the major reforms of 1992 after the initial reforms in January. In July 1992, a unified exchange system replaced most of the system of multiple exchange rates that had existed during the first half of the year. Some minor exceptions to the unified system were brought within it later in the year. The authorities attached great importance to making the ruble free and convertible, and strong pressure from the IMF was not needed. The IMF did, however, play a significant role in helping them identify and phase out the various elements of the multiple exchange system and resist various proposals that would have segmented the market again. There was a major educational element to the IMF's contribution because some Russian officials, while sympathetic to liberalization and unification, did not initially understand all the ramifications of the policy.

The idea of introducing the exchange rate band in July 1995 came from the government, with the CBR being significantly less enthusiastic. The government was concerned about the strong pressures for the exchange rate to appreciate. If appreciation was permitted-and some did in fact take place - this would reduce competitiveness quickly as Russia's inflation was already considerably above that in western trading partners. This could damage export prospects or produce a sharp reversal in the appreciation (the political and economic consequences of Black Tuesday were still fresh in people's minds). If, on the other hand, the appreciation was averted by intervention, in the absence of adequate sterilization instruments noted above, the consequent rapid monetary growth would threaten the achievement of the inflation target. This was already a concern to the government and the IMF. The government hoped that the introduction of the band would persuade financial markets that there was a ceiling to the exchange rate, and markets themselves would keep the rate below the ceiling with little need for intervention. It also hoped that the band would provide some protection against a sharp depreciation should sentiment move in the other direction.

Since the 1992 liberalization, IMF staff had opposed pegging the exchange rate and continued to have doubts about whether fiscal policy would be strong enough to support the peg. However, Fischer had for some years advocated exchange rate-based stabilizations and had encouraged the government to expect a favorable response from the IMF. The IMF was in favor of pegs in many other emerging market countries and had a general policy of accepting countries' choices of exchange rate regime provided that the supporting policies were in place. Therefore, despite some doubts about the fiscal situation and the ultimate exit strategy, the IMF was officially supportive of the authorities' proposal, and the next mission worked closely with them on designing the monetary policy framework that was compatible with the new exchange rate policy.

In the following three years the IMF continued to support the exchange rate band policy. Before each announcement of the band for the next period there would be an exchange of 
views between the IMF and CBR. On all occasions, agreement was reached quickly with little disagreement. The outcome was usually very close to the initial plans of the CBR.

With fiscal policy continuing to be very weak in 1996-98, the burden of supporting the exchange rate peg fell on monetary policy. The resulting policy mix produced a more appreciated real exchange rate than would have been the case if fiscal policy had been tighter. Yet an earlier devaluation without a tightening of fiscal policy would not necessarily have produced a more depreciated real exchange rate other than for a temporary period. ${ }^{56}$ It would, however, have produced higher inflation which would have tended to postpone the recovery in output, thus working in the opposite direction from any real exchange rate effect. The IMF continued to urge the government to go for the first best solution, namely tightening fiscal policy, and did not advocate the alternative approach of a devaluation in, say, $1997 .{ }^{57}$

Given the fiscal policy actually pursued in 1996-98, it is appropriate to ask whether the IMF should have opposed the introduction of the peg in 1995, or at least have insisted on an earlier exit. The absence of the peg might have led to a better outcome for growth in the short term, greater flexibility to deal with the shocks from the Asian crisis and the oil price fall, and no major crisis associated with the exit from the peg. But it would have been at the price of higher inflation, and growth over the medium and long term might have been no better. It is, anyway, difficult to see the grounds on which the IMF could have opposed the peg, given its openness to such arrangements and its commitment to helping the government achieve the reduction in the fiscal deficit that it appeared to want. In supporting the government's fiscal plans, for example the proposed deficits of 4 percent, 3 percent, and 2 percent in 1996, 1997 , and 1998, respectively, in the EFF-supported program, the IMF was implicitly saying that the exchange rate peg was sustainable.

Should the IMF have pressed for an earlier exit as it became clear that the fiscal problems were not being solved? Here one faces the usual dilemma of exit strategies. As long as exchange market conditions are benign, as they were in Russia until the onset of the Asian crisis in late 1997, there is no reason to change the strategy. When market conditions worsen, any attempt to exit the peg arrangement risks creating a crisis. Nevertheless, there was probably a window from November 1997 to March 1998 when people might have been persuaded of the need for an exit, and an orderly exit might have been possible. With hindsight, it is regrettable that the IMF did not spot this opportunity at the time. ${ }^{58}$

\footnotetext{
${ }^{56}$ See Owen (2004) for a fuller discussion of this point.

${ }^{57}$ It should be noted that many commentators, for example Berglöf and Vaitilingam (1999), Kharas, Pinto, and Ulatov (2001) and Stiglitz (2002), have argued that the exchange rate was overvalued before the crisis and an earlier devaluation would have been beneficial. But see the comments of Summers (2001) and Fischer (2001) on the paper by Kharas and others for a defense of the IMF's position.

58 The government was opposed to a devaluation because its credibility and one of its few macroeconomic achievements, the low inflation rate, were linked to the exchange rate peg. It
} 


\section{Conclusions}

This paper is about the IMF's impact on economic policies as they were implemented in Russia in the 1990s. By far the most important determinants of economic policies were the Russian leadership and the many economic agents who were in a position to support or thwart the leadership. The leadership was itself divided, most visibly between the government, which usually had broadly reformist tendencies, and Parliament, which often opposed reforms, in many cases under the influence of economic agents. The government itself was often a coalition of opposing views, and the state was weak. In this situation, economic agents were able to manipulate the law and its implementation to their advantage through their influence, with or without bribes, over government officials and members of parliament.

Given the turbulence of the struggle for economic and political power in the 1990s, it is of little surprise that the IMF was not a dominant force in determining economic policies. Two other factors served to weaken the IMF's influence. First, in the early 1990s, there remained some suspicion of foreign advisors, together with a reluctance, natural in a former superpower, to admit that there were things to be learned. Although this dissipated gradually during the decade, even now the perception persists in some quarters that the IMF's advice is not in Russia's best interests. Second, the G-7's wish to see close IMF engagement in Russia reduced the IMF's ability to insist on ambitious policies and full implementation of agreed programs. Thus, a weakened IMF urged the implementation of strong macroeconomic policies that were supported by the reform wing within government, but were often opposed by stronger groups in the government, parliament, and economy.

The most prominent consequence of the IMF's limited influence was the failure to raise revenues and reduce fiscal deficits, which led to the 1998 crisis. Had the fiscal consolidation that was agreed between the government and the IMF in every year up to 1996 (when the medium-term program to 1998 was agreed) been achieved, it is very unlikely that the crisis would have occurred. It is even possible that a tougher stance by the IMF might have caused the authorities to bring about enough of a consolidation to avert the crisis. The crisis did, however, teach the important lesson that fiscal prudence is important, just as Black Tuesday (October 11, 1994) had taught the lesson that monetary prudence mattered.

Another consequence of the IMF's relative weakness was that it had to focus its efforts on key monetary and fiscal policy issues rather than attempt to affect the whole range of reform policies. Thus, in practice, it had very little influence over structural and institutional reforms outside areas closely linked to the design and implementation of monetary and fiscal policies. In addition, it did not have the mandate or expertise to have an impact on the detailed implementation of the wider agenda of structural and institutional reforms. Its main contribution was to help keep such reforms on the agenda and to emphasize their importance.

would, therefore, have resisted any pressure from the IMF for an early devaluation, although it is possible that it would have eventually relented. 
Its most ambitious effort in this direction was its work, together with the World Bank, on the government's structural reform agenda for 1996-98 in preparation for the EFF. The protection of social expenditures also received a relatively low weight in decisions about how to exert the IMF's influence. A special case of this was the increase in arrears in 1995, which met with undue tolerance from the IMF because the overall fiscal situation had been brought under control for the first time.

Turning now to areas in which the IMF had more of an influence, the most important was monetary policy. The IMF repeatedly presented the case to the authorities for directing monetary policy at producing low inflation and, just as importantly, provided technical assistance on how the CBR should do this operationally. Although the political conditions in 1992-94 were not conducive to the sustained implementation of a serious disinflation strategy, the IMF was laying the foundations for later policies through debates with the CBR and government and operational advice. After conditions changed and the CBR and government economic policy came under new leadership in late 1994, the ground was ripe for the implementation of disinflationary monetary policies. The IMF continued to provide close support during 1995 and subsequent years, and the general success of the policies is seen in the decline in inflation in the years before the 1998 crisis.

Even in fiscal policy the IMF had some impact. Despite the failure at the macroeconomic level, much of the specific advice of the IMF was taken up and implemented by the government. For example, the long struggle to get rid of offsets would probably not have been successful so early if the IMF had not been pushing. And some components of the tax reforms of 2001 were derived in part from technical advice from the IMF in the mid-1990s. However, the IMF's influence was not always positive. It was, for example, a mistake to push for early abolition of the oil export duty and liberalization of the treasury bill market.

Given what we now know about fiscal policy, it might have been better not to have introduced the pegged exchange rate regime in 1995. But the IMF could not have easily prevented it in the face of the government's insistence, as it was in principle open to such arrangements, and it did not expect fiscal policy to be so weak. Similarly, a devaluation before March 1998 might have been better than what actually happened. But this was not obvious at the time, and the government might have resisted any IMF attempts to persuade it to change policy in this direction. Less ambiguous was the positive assistance that the IMF gave to the unification and liberalization of the exchange rate regime in 1992.

This mixed picture of the IMF's impact on specific policies and reforms is only part of the story of the IMF's role in Russia in the 1990s. Another part was the transfer of knowledge to individual officials and experts in the CBR and the government. This took place almost continuously through ongoing discussions about policy issues between the authorities and IMF missions, Moscow office representatives, and resident experts. It occurred at every level, from Camdessus' interactions with Chernomyrdin to discussions about data spreadsheets between economists. What came out of it were, in addition to specific policy improvements, a large number of officials and experts with a fine understanding of macroeconomic policy issues. As time has passed, more of these people have reached senior positions, and the knowledge has spread widely through the key agencies and public bodies. This has ensured that the CBR and the government as a whole now design and manage 
macroeconomic policies in ways recognizably similar to those in western industrial countries. There has also been a related improvement in the quality of the public debate about macroeconomic issues. While the IMF was only one of the elements in this critical transformation of the government's role from central planning to managing a market economy, the transfer of knowledge it brought about may stand as its major legacy from the turbulent 1990s. 


\section{AnNeX: Channels for IMF Advice}

The main channels for IMF advice between 1992 and 2003 were the discussions between visiting staff missions from the European II Department (EU2) of the IMF and their Russian counterparts. In 2003, there was a reorganization of the IMF's area departments, with EU2 disbanded and responsibility for Russia transferred to the European Department (EUR). In 1992-94 and 1997-2001, there were usually five or six missions a year, each lasting about two weeks. In 1995-96, there were monthly missions, although they were shorter in length (seven to ten days). Since 2001, the frequency of missions has declined to two or three a year. During 1992 to 2001, when Russia was borrowing or seeking to borrow from the IMF, much of the policy discussion between the missions and the authorities took the form of a debate about the details of the economic program for the coming period. The annual programs were the most important, but quarterly and monthly programs were also discussed. Typically, drafts of the program documents would be prepared by the IMF team, taking account of both the IMF's views about what was needed and the authorities' objectives. The drafts would be amended to take account of the authorities' views, and negotiations would take place where there were differences of view. Since 2001, the Russian authorities have not sought to borrow from the IMF and the policy dialogue has been less intense. The IMF staff from EU2 therefore focused on giving advice on a few key issues, and backing it up with convincing technical work.

A related channel to that provided by EU2 missions was the work of the staff located in the IMF Moscow office. Their role has varied according to the frequency of EU2 missions. When these were very frequent, Moscow office staff spent most of their time supporting the missions. When the missions were less frequent, especially in recent years, the Moscow office staff have played an important role in advising the Russian authorities directly. One advantage they have in this role over their colleagues at IMF headquarters is that they have time to develop both a deeper knowledge of specific issues and closer personal relationships with counterparts. The latter quality led in a few specific cases to particular Moscow office staff members acting as part-time advisors to senior officials in the CBR or the finance ministry.

A third channel for advice was technical assistance. This took the form of missions of technical experts and resident technical advisors who advised on particular issues, especially the development of the capacity of the CBR and ministry of finance to design and implement monetary and fiscal policies. In the ten year period from May 1991 to April 2001, 63 person years of IMF technical assistance (TA) were provided, which was nearly 4 percent of the IMF's worldwide TA provision (Table A.1). 
Table A.1. IMF Technical Assistance Work in Russia

\begin{tabular}{ccc}
\hline Fiscal Year* & $\begin{array}{c}\text { Number of } \\
\text { Person-Years }\end{array}$ & $\begin{array}{c}\text { In Percent of } \\
\text { Worldwide Total }\end{array}$ \\
\hline 1992 & 3.2 & 2.4 \\
1993 & 7.2 & 4.8 \\
1994 & 9.6 & 6.7 \\
1995 & 12.1 & 7.2 \\
1996 & 8.8 & 4.2 \\
1997 & 6.1 & 3.3 \\
1998 & 4.0 & 2.7 \\
1999 & 4.6 & 2.3 \\
2000 & 3.9 & 2.0 \\
2001 & 3.6 & 1.9 \\
& & 3.7 \\
Total & 63.1 & \\
* The fiscal year runs from May of the previous year to April of the year shown \\
in this column
\end{tabular}

In the four peak years, May 1992 to April 1996, nearly 6 percent of the IMF's worldwide TA effort was devoted to Russia. In the early 1990s, well over half of the technical assistance to Russia was devoted to the development of the CBR as a modern central bank. The rest was mostly assistance in the fiscal area, which included tax policy advice, tax administration and the creation of the treasury. As the details in Table A. 2 show, this assistance was concentrated on tax administration and the treasury. All of the long-term resident advisors, who accounted for over half of the total fiscal TA provision, worked in these two areas. There was also assistance on statistics and drafting legislation. Details of the technical assistance in the central banking area in Russia and other transition countries in the region are available in Zulu and others (1994), Sundararajan and others (1997) and Knight (1997). Details of the work on setting up treasuries in Russia and the other countries of the region are in Potter and Diamond (2000), and those on reforming budget systems in Russia are in Diamond (2001 and 2002).

The fourth channel for IMF advice was less direct. The IMF has organized many courses for government and CBR officials at its training institutes in Washington and Vienna. It has also invited officials, parliamentarians, and journalists to seminars in Washington, Vienna, and centers in Russia. These courses and seminars covered economic policies in general, economic policies in transition and specific Russian policy issues. They did not in general address immediate current policy issues, unlike the policy advice provided by EU2 missions and Moscow Office staff. 
Table A.2. IMF Technical Assistance in the Fiscal Area

A. Short visits (number of visits) $1 /$

Fiscal Tax Tax

year 2/

Policy

Admin.

$\begin{array}{cc}\text { Treasury } & \begin{array}{r}\text { Social } \\ \text { Sector }\end{array} \\ 1 & 1 \\ 6 & \\ 14 & 1 \\ 6 & \\ 5 & \\ 1 & \\ & \\ 1 & \\ 2 & \\ 2 & \end{array}$

$\begin{array}{ccc}\text { Public Exp. } & \begin{array}{c}\text { Other } \\ \text { Management }\end{array} & \text { Total } \\ & 2 & 8 \\ & 2 & 12 \\ & 1 & 17 \\ & & 8 \\ & 2 & 11 \\ & 2 & 6 \\ & 1 & 4 \\ 6 & 2 & 6 \\ & 14 \\ & & \text { Total } \\ & & \text { (person- } \\ & \text { years) }\end{array}$

\section{B. Long-term resident advisors}

Tax administration $\quad 4.4$

February 1993-June 1997

Treasury software

March 1994-September 1995

Tax administration

1.6

July 1994-December 1995

September 1997-August 1999

Treasury

1.5

Tax administration

2.0

February 1999-August 2001

Treasury

\section{Short and long-term technical assistance (person-years)}

$\begin{array}{lccc}\text { Fiscal year 2/ } & \begin{array}{c}\text { Short } \\ \text { visits 1/ }\end{array} & \begin{array}{c}\text { Long-term } \\ \text { advisors }\end{array} & \text { Total } \\ 1992 & 1.7 & 0.0 & 1.7 \\ 1993 & 2.5 & 0.3 & 2.8 \\ 1994 & 2.3 & 1.5 & 3.8 \\ 1995 & 1.3 & 3.8 & 5.1 \\ 1996 & 0.6 & 2.8 & 3.4 \\ 1997 & 1.0 & 1.0 & 2.0 \\ 1998 & 0.4 & 0.9 & 1.3 \\ 1999 & 0.4 & 1.2 & 1.6 \\ 2000 & 0.7 & 1.3 & 2.0 \\ 2001 & 1.0 & 1.0 & 2.0 \\ \text { Total } & 11.9 & 13.8 & 25.7\end{array}$

$1 /$ Includes visits lasting from a few days to a few months, comprising both single experts and teams. 2/ The fiscal year runs from May of the previous year to April of the year shown in this column. 3 / Includes missions on general budget making and fiscal monitoring, participation in World Bank missions and other visits. 


\section{References}

Allison, Graham, and Grigory Yavlinsky, 1991, Window of Opportunity (New York: Pantheon Books).

Anderson, Jonathan, Daniel A. Citrin, and Ashok K. Lahiri, 1995, "The Decline in Output" in Policy Experiences and Issues in the Baltics, Russia, and Other Countries of the Former Soviet Union, ed. by Daniel Citrin and Ashok Lahiri, IMF Occasional Paper No. 133 (Washington: International Monetary Fund).

Åslund, Anders, 2002, Building Capitalism: The Transformation of the Former Soviet Block (Cambridge, England: Cambridge University Press).

Berglöf, Erik, and Ramesh Vaitilingam, 1999, Stuck in Transit: Rethinking Russian Economic Reform (London: CEPR; Moscow: RECEP; and Stockholm: SITE).

Camdessus, Michel, 1992, "Economic Transformation in the Fifteen Republics of the Former USSR: A Challenge or an Opportunity for the World?" address to Georgetown University School of Foreign Service, Washington, DC, April 15, 1992.

— 1994, "The Transformation of the Russian Economy: Progress Made, Challenges Remaining, and the Role of the IMF," address at the Moscow Finance Academy, Moscow, March 21.

$\ldots$, 1997, address at the Moscow Institute of International Affairs, Moscow, April 2.

Cheasty, Adrienne, and Jeffrey M. Davis, 1996, "Fiscal Transition in Countries of the Former Soviet Union: An Interim Assessment,” MOCT-MOST, Vol. 6, No. 3 pp. 7-34.

Chu, Ke-young and Sanjeev Gupta, 1996, "Social Protection in Transition Economies: Emerging Issues," MOCT-MOST, Vol. 6, No. 3, pp. 107-123.

Citrin, Daniel A., 1995, "Overview," in Policy Experiences and Issues in the Baltics, Russia, and Other Countries of the Former Soviet Union, ed. by Daniel Citrin and Ashok Lahiri, IMF Occasional Paper No. 133 (Washington: International Monetary Fund).

Citrin, Daniel, and Ashok K. Lahiri, ed.,1995, Policy Experiences and Issues in the Baltics, Russia, and Other Countries of the Former Soviet Union, IMF Occasional Paper No. 133 (Washington: International Monetary Fund).

Diamond, Jack, 2001, "The New Russian Budget System: A Critical Assessment and Future Reform Agenda”, IMF Working Paper No. 02/21 (Washington: International Monetary Fund).

_ , 2002, "Budget System Reform in Transitional Economies: The Experience of Russia”, IMF Working Paper No. 02/22 (Washington: International Monetary Fund). 
Dubinin, Sergei K., 1995, "Macroeconomic Stabilization in Russia: The Lessons of 1992-95 and the Outlook for 1996-97," in Economic Transformation: The Tasks Still Ahead, (Washington: Per Jacobsson Foundation).

Fischer, Stanley, 2001, "Comments and Discussion," Brookings Papers on Economic Activity, 1:2001, pp. 62-64 (Washington: The Brookings Institution).

Fischer, Stanley and Ratna Sahay, 2000, "The Transition Economies after Ten Years," IMF Working Paper No. 00/30 (Washington: International Monetary Fund).

Freeland, Chrystia, 2000, Sale of the Century (New York: Crown Business).

Gaidar, Yegor, 1997, “The IMF and Russia," AEA Papers and Proceedings, Vol. 87, No. 2, May 1997 pp.13-16.

— 1999, Days of Defeat and Victory (Seattle: University of Washington Press).

Graham, Thomas E., 2002, Russia's Decline and Uncertain Recovery (Washington: Carnegie Endowment for International Peace).

Hernández-Catá, Ernesto, 1995, "Russia and the IMF: The Political Economy of Macrostabilization," in Policy Experiences and Issues in the Baltics, Russia, and Other Countries of the Former Soviet Union, ed. by Daniel Citrin and Ashok Lahiri, IMF Occasional Paper No. 133 (Washington: International Monetary Fund).

International Monetary Fund, Fiscal Affairs Department, 1995, "Social Safety Nets for Economic Transition: Options and Recent Experiences," IMF Paper on Policy Analysis and Assessment 95/3 (Washington: International Monetary Fund).

International Monetary Fund, International Bank for Reconstruction and Development, Organization for Economic Cooperation and Development, and European Bank for Reconstruction and Development, 1990, The Economy of the USSR: Summary and Recommendations, a study undertaken in response to a request by the Houston Summit.

Kalra, Sanjay, and Torsten Sløk, 2001, "Inflation and Growth in Transition: Are the Asian Economies Different?" in A Decade of Transition: Achievements and Challenges, ed. by Oleh Havrylyshyn and Saleh M. Nsouli (Washington: International Monetary Fund).

Kharas, Homi, Brian Pinto and Sergei Ulatov, 2001, “An Analysis of Russia’s 1998 Meltdown: Fundamentals and Market Signals," Brookings Papers on Economic Activity, 1:2001, pp. 1-50 (Washington: The Brookings Institution). 
Klyamkin, Igor and Lilia Shevtsova, 1999, This Omnipotent and Impotent Government: The Evolution of the Political System of Post-Soviet Russia (Washington: Carnegie Endowment for International Peace).

Knight, Malcolm et al., 1997, Central Bank Reforms in the Baltics, Russia, and the Other Countries of the Former Soviet Union, IMF Occasional Paper No. 157 (Washington: International Monetary Fund).

Lopez-Claros, Augusto, 2002, "The Role of the International Financial Institutions During the Transition in Russia," Institute for the Economy in Transition, Moscow, web-site, posted December 18, 2002.

Mau, Vladimir, 2000, "Russian Economic Reforms as Perceived by Western Critics," in Russian Crisis and its Effects, ed. by Tuomas Komulainen and Iikka Korhunen, (Helsinki: Kikimora Publications).

Nagy, Piroska Mohácsi, 2000, The Meltdown of the Russian State: The Deformation and Collapse of the State in Russia (Cheltenham, United Kingdom: Edward Elgar Publishing).

Odling-Smee, John, 1996, "The IMF's Approach to Economies in Transition," in Fifty years After Bretton Woods: The New Challenge of East-West Partnership for Economic Progress, ed. by Miklós Szabó-Pelsöczi, (Aldershot, United Kingdom: Avebury).

Odling-Smee, John and Gonzalo Pastor, 2002, “The IMF and the Ruble Area, 1991-93," Comparative Economic Studies, Vol. XLIV, No. 4, Winter 2002, pp. 3-29 and 81-84.

Odling-Smee, John and Thomas Wolf, 1994, "Economic Reforms in Transition Economies: A Macroeconomic Perspective on the Baltic States, Russia and Other Countries of the Former Soviet Union," presented at a seminar on Economic Reform in Russia and Other Countries in Transition: Issues and Prospects, Moscow, October 18-19.

Owen, David, 2004, "Russian Economic Programs and Policies in the 1990s," IMF Working Paper, forthcoming 2004.

Owen, David and David Robinson, eds., 2003, Russia Rebounds (Washington: International Monetary Fund).

Potter, Barry H., and Jack Diamond, 2000, Setting Up Treasuries in the Baltics, Russia, and Other Countries of the Former Soviet Union: An Assessment of IMF Technical Assistance, IMF Occasional Paper No. 198 (Washington: International Monetary Fund).

Primakov, Yevgeny, 2001, Vosem Mesiatsev Plius [Eight Months Plus] (Moscow: publisher not known). 
Sachs, Jeffrey D., and Wing Thye Woo, 1994, "Reform in China and Russia," Economic Policy, No.18, pp. 101-145.

Stiglitz, Joseph, 2002, Globalization and Its Discontents (New York: Norton).

Summers, Lawrence, 2001, "Comments and Discussion," Brookings Papers on Economic Activity, 1:2001, pp. 51-57 (Washington: The Brookings Institution).

Sundararajan, V., Arne B. Petersen, and Gabriel Sensenbrenner, eds., 1997, Central Bank Reform in the Transition Economies (Washington: International Monetary Fund).

Talbot, Strobe, 2003, The Russia Hand: A Memoir of Presidential Diplomacy (New York: Random House).

World Bank, 2003, Assisting Russia's Transition: An Unprecedented Challenge (Washington: The World Bank).

Zulu, J.B., Ian S. McCarthy, Susana Almuiña, and Gabriel Sensenbrenner, 1994, Central Banking Technical Assistance to Countries in Transition (Washington: International Monetary Fund). 